\title{
Ditopic $N$-Heterocyclic Pincer Carbene Complexes Containing a Perylene Backbone
}

\author{
Susanne Langbein, Hubert Wadepohl, Lutz H. Gade* \\ Anorganisch-Chemisches Institut, Universität Heidelberg, Im Neuenheimer Feld 270, 6912o Heidelberg, \\ Germany.
}

Table of Contents:

Crystallographic data

$\mathrm{S} 2$

NMR spectra of new compounds

S7

IR spectra of compounds $3 \mathrm{a}$ and $3 \mathrm{~b}$

$\mathrm{S} 18$

Absorptionspectra of new compounds

S19

Emission and excitation fluorescence spectra of new compounds

S19 
Summary of Data CCDC 1442271

Compound Name: 1a

Formula: C74 H60 N4 P4

Unit Cell Parameters: a 8.02610(19) b 30.4330(7) c 11.5232(2) P21/c

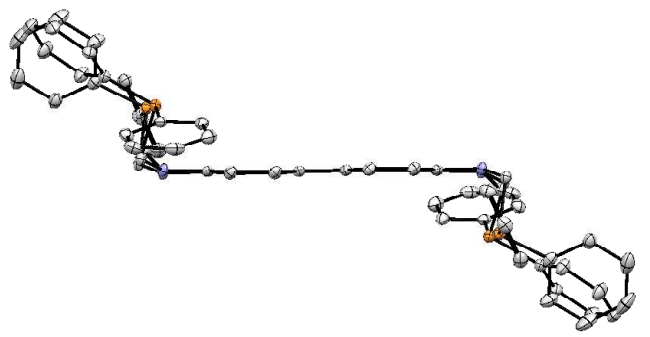

Figure S 1. Side view of the molecular structure of 1a. The ellipsoids are drawn with a $50 \%$ probability level. The hydrogen atoms are omitted for clarity.

Summary of Data CCDC 1442272

Compound Name: $1 \mathrm{~b}$

Formula: C74 H108 N4 P4

Unit Cell Parameters: a 31.8240(9) b 11.1607(4) c 18.8439(4) P21/c

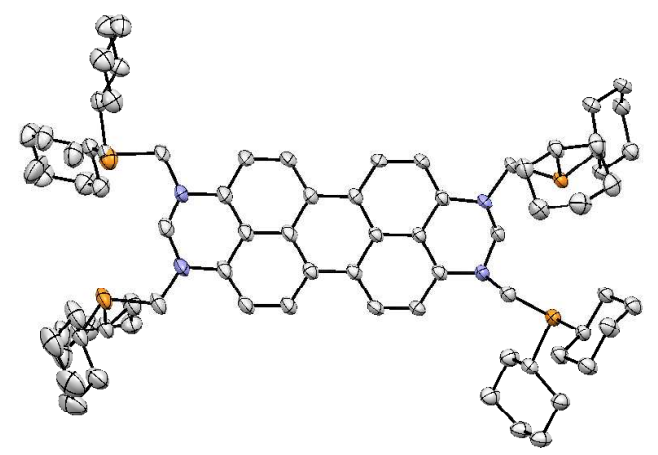

Figure S 2. Front view of the molecular structure of $\mathbf{1 b}$. The ellipsoids are drawn with a $50 \%$ probability level. The hydrogen atoms are omitted for clarity. 
Compound Name: 1c

Formula: C50 H76 N4 P4,C6 H6

Unit Cell Parameters: a 35.8845(9) b 15.2434(3) c 9.6886(2) C2/c
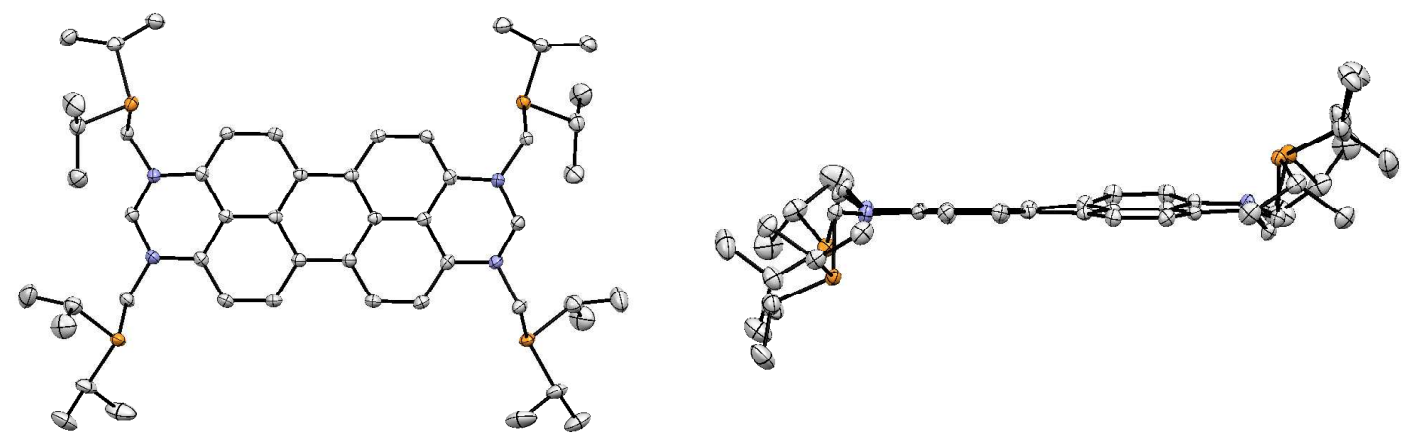

Figure S 3. Front view (left) and side view (right) of the molecular structure of 1c. The ellipsoids are drawn with a $50 \%$ probability level. The hydrogen atoms are omitted for clarity.

Summary of Data CCDC 1442274

Compound Name: $2 \mathrm{c}$

Formula: C50 H72 Cl2 N4 P4 Rh2,C4 H8 O1

Unit Cell Parameters: a 27.9454(3) b 13.70389(12) c 15.62974(19) Pna21

\section{X-ray Crystal Structure Determinations}

Crystal data and details of the structure determinations are compiled in Table S1. Full shells of intensity data were collected at low temperature with an Agilent Technologies SupernovaE CCD diffractometer (Mo- or $\mathrm{Cu}-K_{\mathrm{a}}$ radiation, microfocus X-ray tube, multilayer mirror optics). Data were corrected for air and detector absorption, Lorentz and polarization effects; ${ }^{1}$ absorption by the crystal was treated numerically (Gaussian grid). ${ }^{1,2}$ The structures were solved by "modern" direct methods (compound $1 \mathrm{~b}$ ) 3 or by the charge flip procedure (all other compounds) ${ }^{4}$ and refined by full-matrix least squares methods based on $F^{2}$ against all unique reflections. ${ }^{5}$ All non-hydrogen atoms were given anisotropic displacement parameters. Hydrogen atoms were generally input at calculated positions and refined with a riding model. For compound 1a the positions of the hydrogen atoms were taken from difference Fourier syntheses and refined. When found necessary, disordered groups and/or solvent molecules were subjected to suitable geometry and adp restraints. 
Due to severe disorder and fractional occupancy, electron density attributed to solvent of crystallization (thf) was removed from the structure of $2 \mathrm{c}$ with the BYPASS procedure, ${ }^{6}$ as implemented in PLATON (SQUEEZE). ${ }^{7}$ Partial structure factors from the solvent masks were included in the refinement as separate contributions to $F_{\text {obs }}$.

1 CrysAlisPro, Agilent Technologies UK Ltd., Oxford, UK 2011-2014 and Rigaku Oxford Diffraction, Rigaku Polska Sp.z o.o., Wrocław, Poland 2015.

2 Busing, W. R.; Levy, H. A. Acta Cryst. 1957, 10, 180.

3 (a) Burla, M. C.; Caliandro, R.; Carrozzini, B.; Cascarano, G. L.; Cuocci, C.; Giacovazzo, C.; Mallamo, M.; Mazzone, A.; Polidori, G. SIR2014, CNR IC, Bari, Italy, 2014; (b) Burla, M. C.; Caliandro, R.; Carrozzini, B.; Cascarano, G. L.; Cuocci, C.; Giacovazzo, C.; Mallamo, M.; Mazzone, A.; Polidori, G. J. Appl. Cryst. 2015, 48, 306.

4 (a) Palatinus, L. SUPERFLIP, EPF Lausanne, Switzerland and Fyzikální ústav AV ČR, v. v. i., Prague, Czech Republic, 2007-2014 (b) Palatinus, L.; Chapuis, G. J. Appl. Cryst. 2007, 40, 786.

5 (a) Sheldrick, G. M. SHELXL-20xx, University of Göttingen and Bruker AXS GmbH, Karlsruhe, Germany 2012-2014; (b) Sheldrick, G. M. Acta Cryst. 2008, A64, 112; (c) Sheldrick, G. M. Acta Cryst. 2015, C71, 3.

6 (a) v. d. Sluis, P.; Spek, A. L. Acta Cryst. 1990, A46, 194; (b) Spek, A. L. Acta Cryst. 2015, C71, 9.

7 (a) Spek, A. L. PLATON, Utrecht University, The Netherlands; (b) Spek, A. L. J. Appl. Cryst. 2003, $36,7$. 
Table S 1. Details of the crystal structure determinations of 1a, $1 \mathrm{~b}$.

\begin{tabular}{|c|c|c|}
\hline & $1 \mathbf{a}$ & $1 \mathbf{b}$ \\
\hline formula & $\mathrm{C}_{74} \mathrm{H}_{60} \mathrm{~N}_{4} \mathrm{P}_{4}$ & $\mathrm{C}_{74} \mathrm{H}_{108} \mathrm{~N}_{4} \mathrm{P}_{4}$ \\
\hline crystal system & monoclinic & monoclinic \\
\hline space group & $P 2{ }_{1} / c$ & $P 2{ }_{1} / c$ \\
\hline$a[\AA]$ & $8.02610(19)$ & $31.8240(9)$ \\
\hline$b[\AA]$ & $30.4330(7)$ & $11.1607(4)$ \\
\hline$c[\AA]$ & $11.5232(2)$ & $18.8439(4)$ \\
\hline$\beta\left[^{\circ}\right]$ & $91.934(2)$ & $95.693(2)$ \\
\hline$V\left[\AA^{3}\right]$ & 2813.04(11) & $6660.0(3)$ \\
\hline$Z$ & 2 & 4 \\
\hline$M_{\mathrm{r}}$ & 1129.14 & 1177.52 \\
\hline$F_{000}$ & 1184 & 2560 \\
\hline$d_{\mathrm{c}}\left[\mathrm{Mg} \cdot \mathrm{m}^{-3}\right]$ & 1.333 & 1.174 \\
\hline$\mu\left[\mathrm{mm}^{-1}\right]$ & 0.185 & 1.378 \\
\hline max., min. transmission factors & 0.997, 0.981 & $0.971,0.865$ \\
\hline X-radiation, $\lambda[\AA]$ & Mo- $K \alpha, 0.71073$ & $\mathrm{Cu}-K \alpha, 1.54184$ \\
\hline data collect. temperat. [K] & $110(1)$ & $120(1)$ \\
\hline$\theta$ range $\left[{ }^{\circ}\right]$ & 3.2 to 28.3 & 4.2 to 67.1 \\
\hline index ranges $h, k, l$ & $-10 \ldots 10,-39 \ldots 38,-14 \ldots 15$ & $-38 \ldots 38,-13 \ldots 13,-22 \ldots 22$ \\
\hline reflections measured & 54562 & 353291 \\
\hline unique $\left[R_{\text {int }}\right]$ & $6829[0.0858]$ & $11897[0.1705]$ \\
\hline observed $[I \geq 2 \sigma(I)]$ & 5120 & 8462 \\
\hline data / restraints /parameters & $6829 / 0 / 460$ & 11897 / 955 / 884 \\
\hline GooF on $F^{2}$ & 1.027 & 1.042 \\
\hline $\begin{array}{l}R \text { indices }[F>4 \sigma(F)] R(F) \\
w R\left(F^{2}\right)\end{array}$ & $0.0489,0.0974$ & $0.0685,0.1612$ \\
\hline $\begin{array}{l}R \text { indices (all data) } R(F), w R\left(F^{2}\right) \\
\text { absolute structure parameter }\end{array}$ & $0.0743,0.1078$ & $0.1018,0.1792$ \\
\hline largest residual peaks $\left[\mathrm{e} \cdot \AA^{-3}\right]$ & $0.407,-0.314$ & $1.148,-0.394$ \\
\hline
\end{tabular}


Table S 2. Details of the crystal structure determinations of 1c, $2 \mathrm{c}$.

\begin{tabular}{|c|c|c|}
\hline & 1c & $2 c$ \\
\hline formula & $\mathrm{C}_{56} \mathrm{H}_{82} \mathrm{~N}_{4} \mathrm{P}_{4}$ & $\mathrm{C}_{58} \mathrm{H}_{88} \mathrm{Cl}_{2} \mathrm{~N}_{4} \mathrm{O}_{2} \mathrm{P}_{4} \mathrm{Rh}_{2}$ \\
\hline crystal system & monoclinic & orthorhombic \\
\hline space group & $C 2 / c$ & $P n a 2_{1}$ \\
\hline$a[\AA]$ & $35.8845(9)$ & $27.9454(3)$ \\
\hline$b[\AA]$ & $15.2434(3)$ & $13.70389(12)$ \\
\hline$c[\AA]$ & $9.6886(2)$ & $15.62974(19)$ \\
\hline$\beta\left[^{\circ}\right]$ & $91.239(2)$ & \\
\hline$V\left[\AA^{3}\right]$ & $5298.5(2)$ & $5985.58(11)$ \\
\hline$Z$ & 4 & 4 \\
\hline$M_{\mathrm{r}}$ & 935.13 & 1273.92 \\
\hline$F_{000}$ & 2024 & 2656 \\
\hline$d_{\mathrm{c}}\left[\mathrm{Mg} \cdot \mathrm{m}^{-3}\right]$ & 1.172 & 1.414 \\
\hline$\mu\left[\mathrm{mm}^{-1}\right]$ & 1.608 & 0.791 \\
\hline max., min. transmission factors & $0.965,0.808$ & $0.967,0.912$ \\
\hline $\mathrm{X}$-radiation, $\lambda[\AA]$ & $\mathrm{Cu}-K \alpha, 1.54184$ & Mo- $K \alpha, 0.71073$ \\
\hline data collect. temperat. [K] & $120(1)$ & $120(1)$ \\
\hline$\theta$ range $\left[{ }^{\circ}\right]$ & 4.7 to 70.7 & 3.3 to 30.5 \\
\hline index ranges $h, k, l$ & $-41 \ldots 43,-18 \ldots 18,-11 \ldots 11$ & $-39 \ldots 39,-19 \ldots 19,-22 \ldots 22$ \\
\hline reflections measured & 69633 & 324309 \\
\hline unique $\left[R_{\text {int }}\right]$ & $5072[0.0549]$ & $18298[0.0780]$ \\
\hline observed $[I \geq 2 \sigma(I)]$ & 4271 & 16545 \\
\hline data / restraints / parameters & $5072 / 36 / 312$ & 18298 / 634 / 631 \\
\hline GooF on $F^{2}$ & 1.025 & 1.023 \\
\hline $\begin{array}{l}R \text { indices }[F>4 \sigma(F)] R(F) \\
w R\left(F^{2}\right)\end{array}$ & $0.0338,0.0848$ & $0.0486,0.1245$ \\
\hline $\begin{array}{l}R \text { indices (all data) } R(F), w R\left(F^{2}\right) \\
\text { absolute structure parameter }\end{array}$ & $0.0431,0.0898$ & $\begin{array}{l}0.0546,0.1282 \\
\quad 0.050(8)\end{array}$ \\
\hline largest residual peaks $\left[\mathrm{e} \cdot \AA^{-3}\right]$ & $0.270,-0.189$ & $2.987,-0.840$ \\
\hline
\end{tabular}




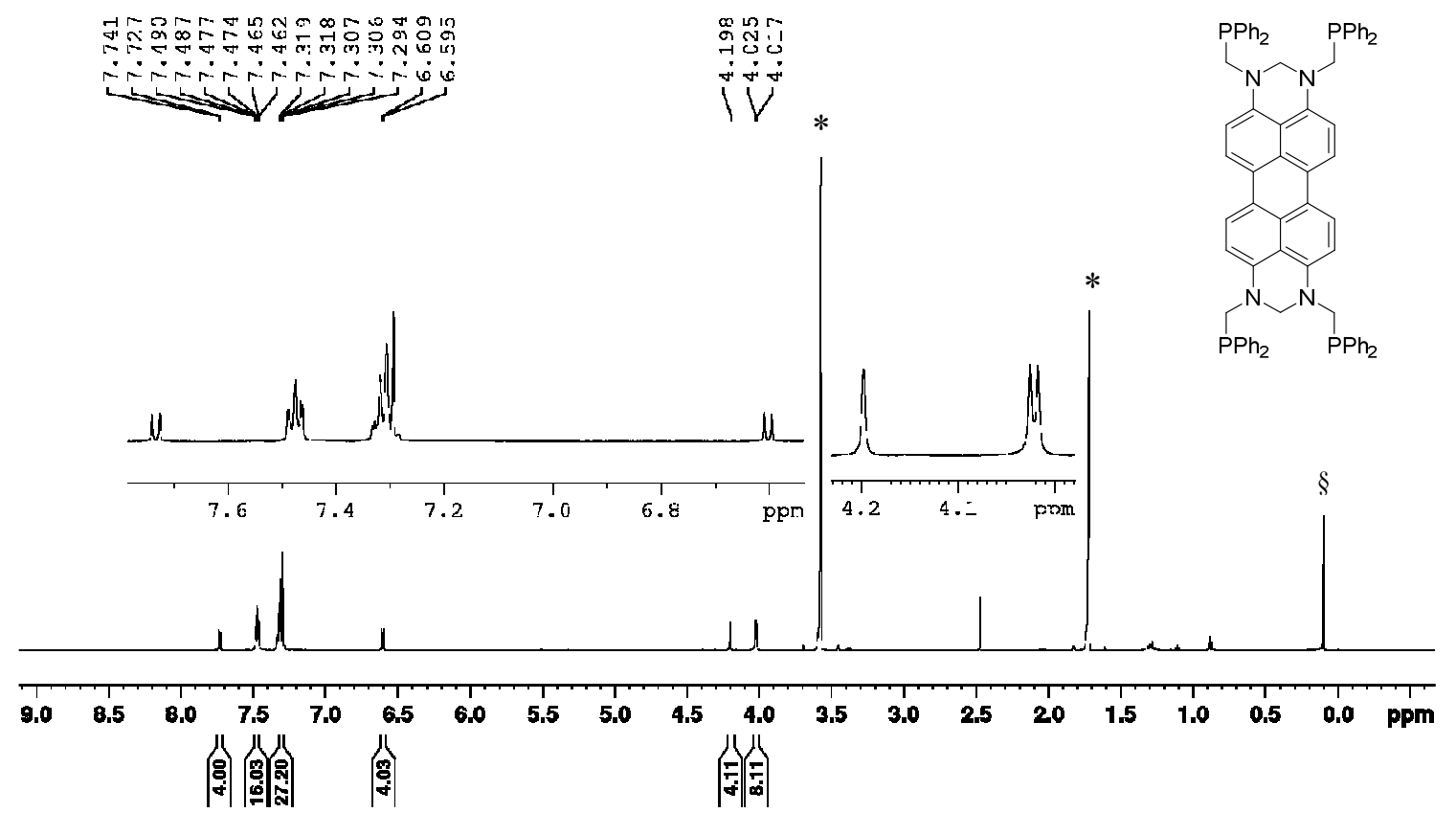

Figure S 4. ${ }^{1} \mathrm{H}$ NMR $\left(600.13 \mathrm{MHz}, \mathrm{THF}-\mathrm{d}_{8}\right)$ of 1a. Silicon grease is labelled with $\S$ and residual proton signals of THF- $\mathrm{d}_{8}$ are labelled with *.

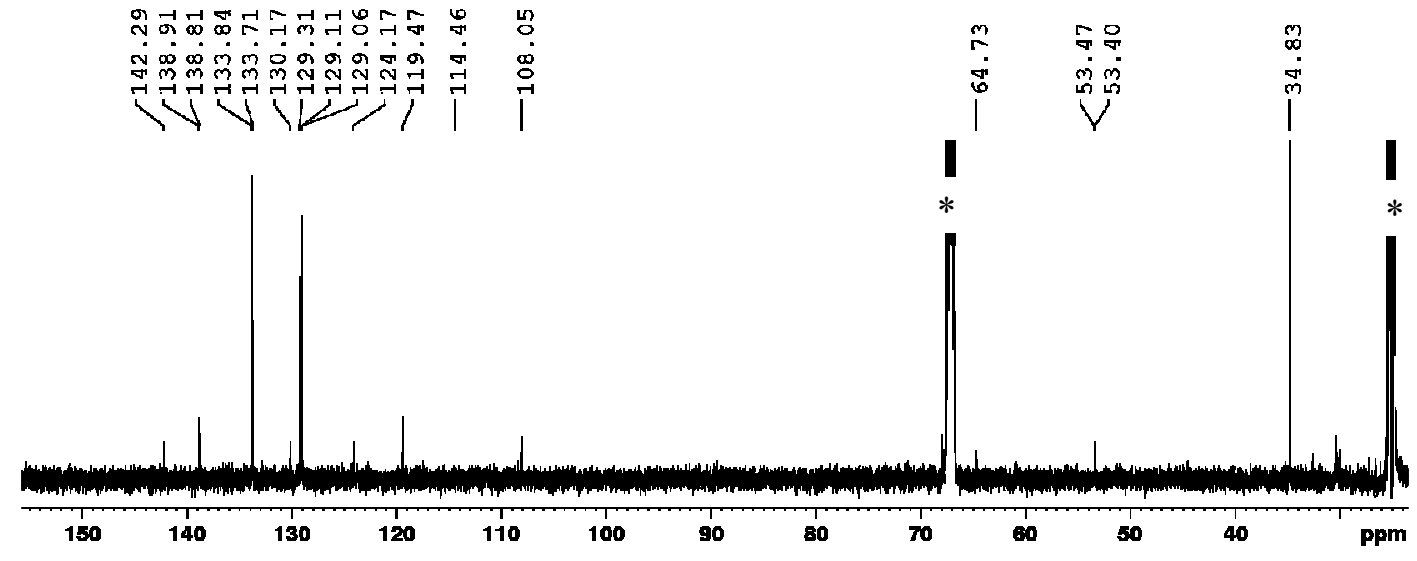

Figure S 5. ${ }^{13} \mathrm{C}$ NMR $\left(150.90 \mathrm{MHz}, \mathrm{THF}-\mathrm{d}_{8}\right)$ of $\mathbf{1 a}$. Residual carbon signals of THF-d $\mathrm{d}_{8}$ are labelled with *.

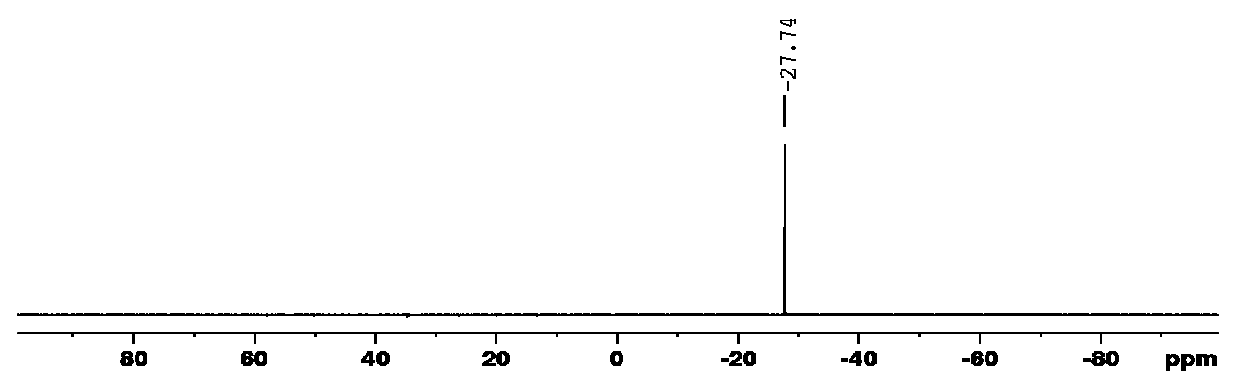

Figure S 6. ${ }^{31} \mathrm{P}$ NMR $\left(242.94 \mathrm{MHz}, \mathrm{THF}-\mathrm{d}_{8}\right)$ of $\mathbf{1 a}$. 


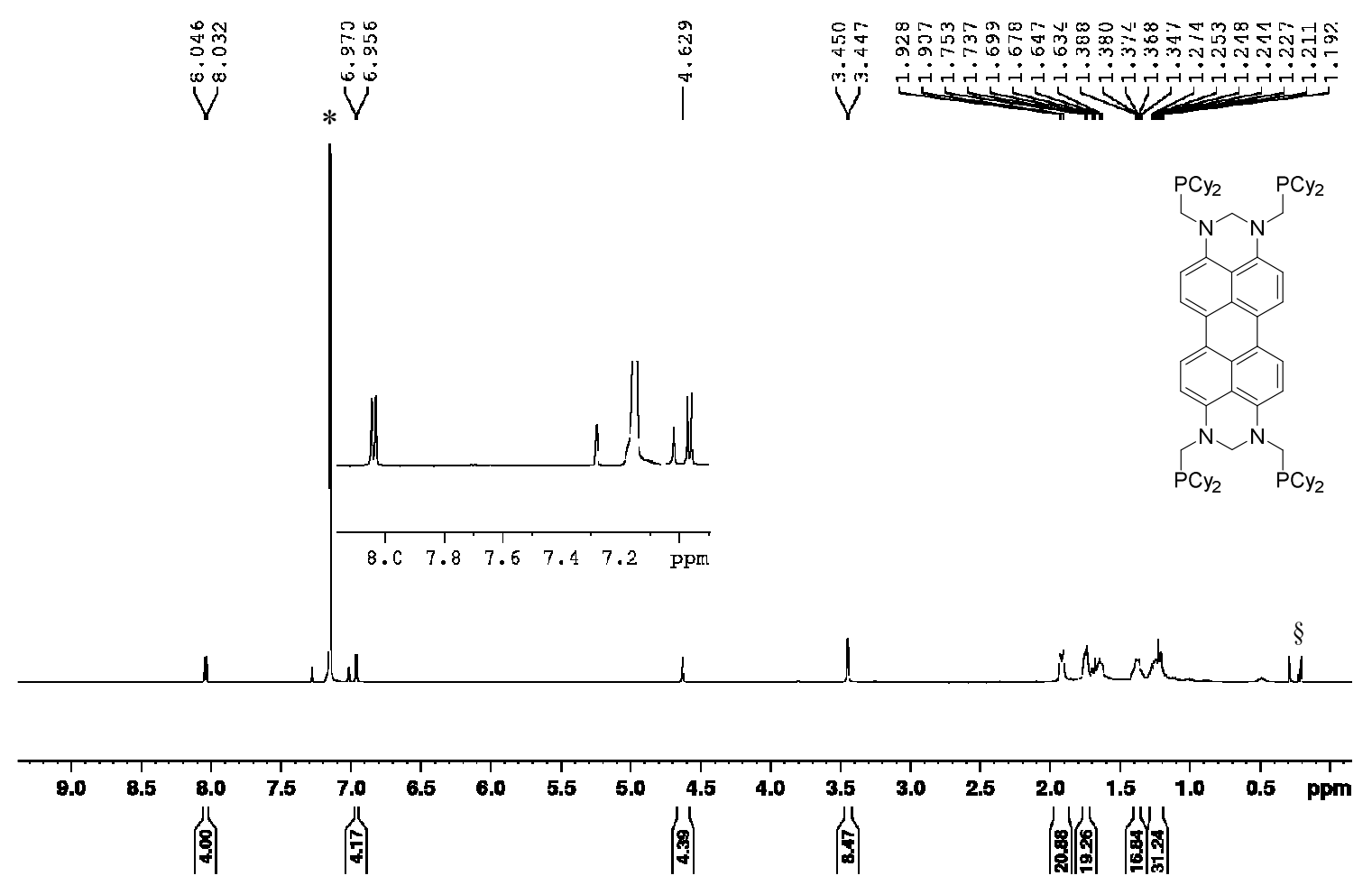

Figure S 7. ${ }^{1} \mathrm{H}$ NMR $\left(600.13 \mathrm{MHz}, \mathrm{C}_{6} \mathrm{D}_{6}\right)$ of $\mathbf{1 b}$. Silicon grease is labelled with $\S$ and residual proton signal of $\mathrm{C}_{6} \mathrm{D}_{6}$ with *.

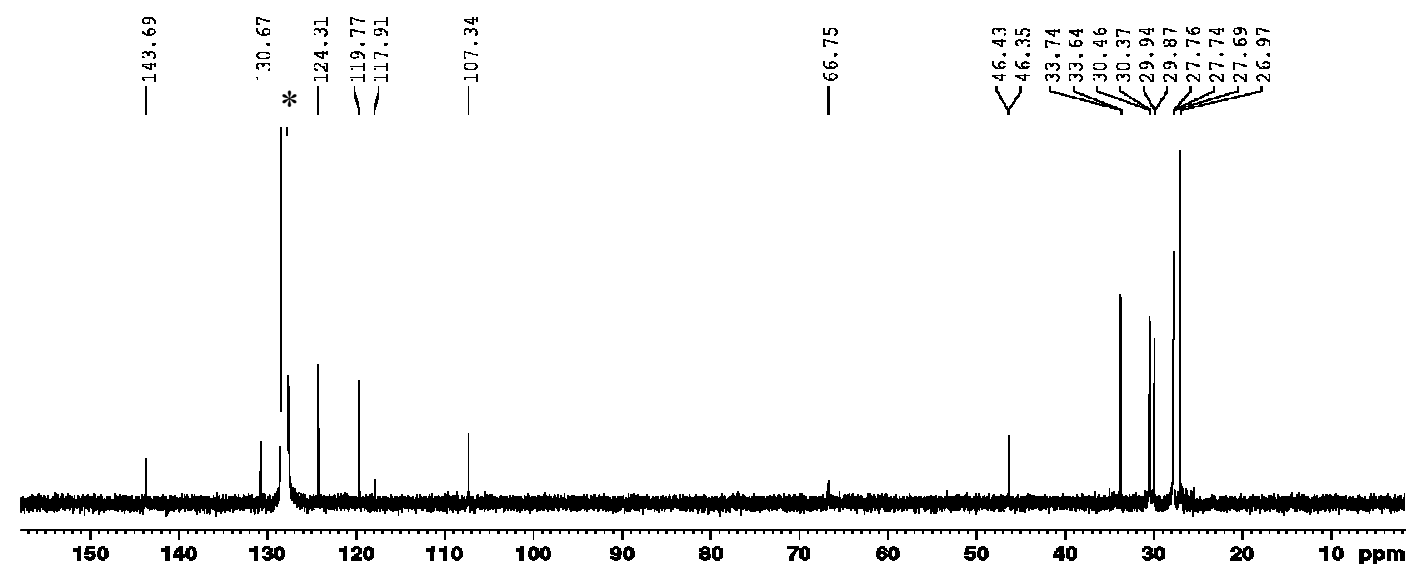

Figure S 8. ${ }^{13} \mathrm{C}$ NMR $\left(150.90 \mathrm{MHz}, \mathrm{C}_{6} \mathrm{D}_{6}\right)$ of $\mathbf{1 b}$. Residual carbon signal of $\mathrm{C}_{6} \mathrm{D}_{6}$ islabelled with *.

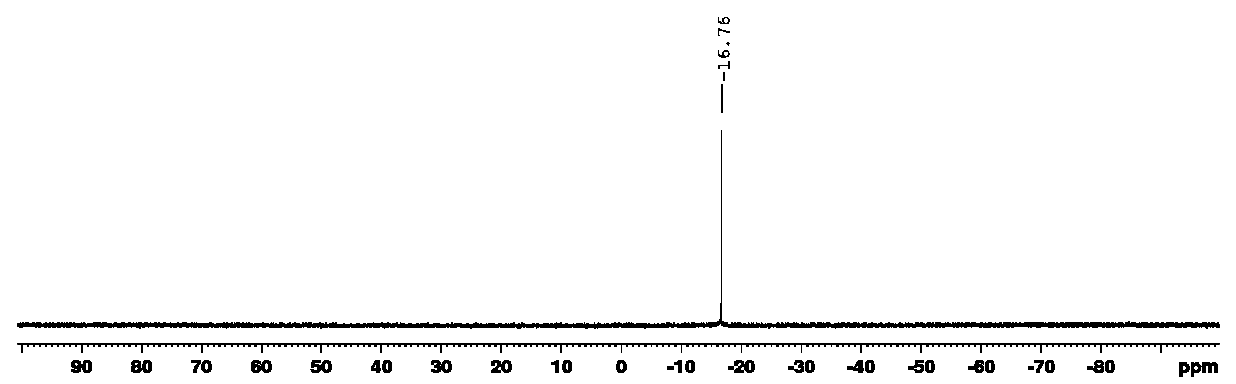

Figure $\mathbf{S} 9 .{ }^{31} \mathrm{P}$ NMR $\left(242.94 \mathrm{MHz}, \mathrm{C}_{6} \mathrm{D}_{6}\right)$ of $\mathbf{1 b}$. 


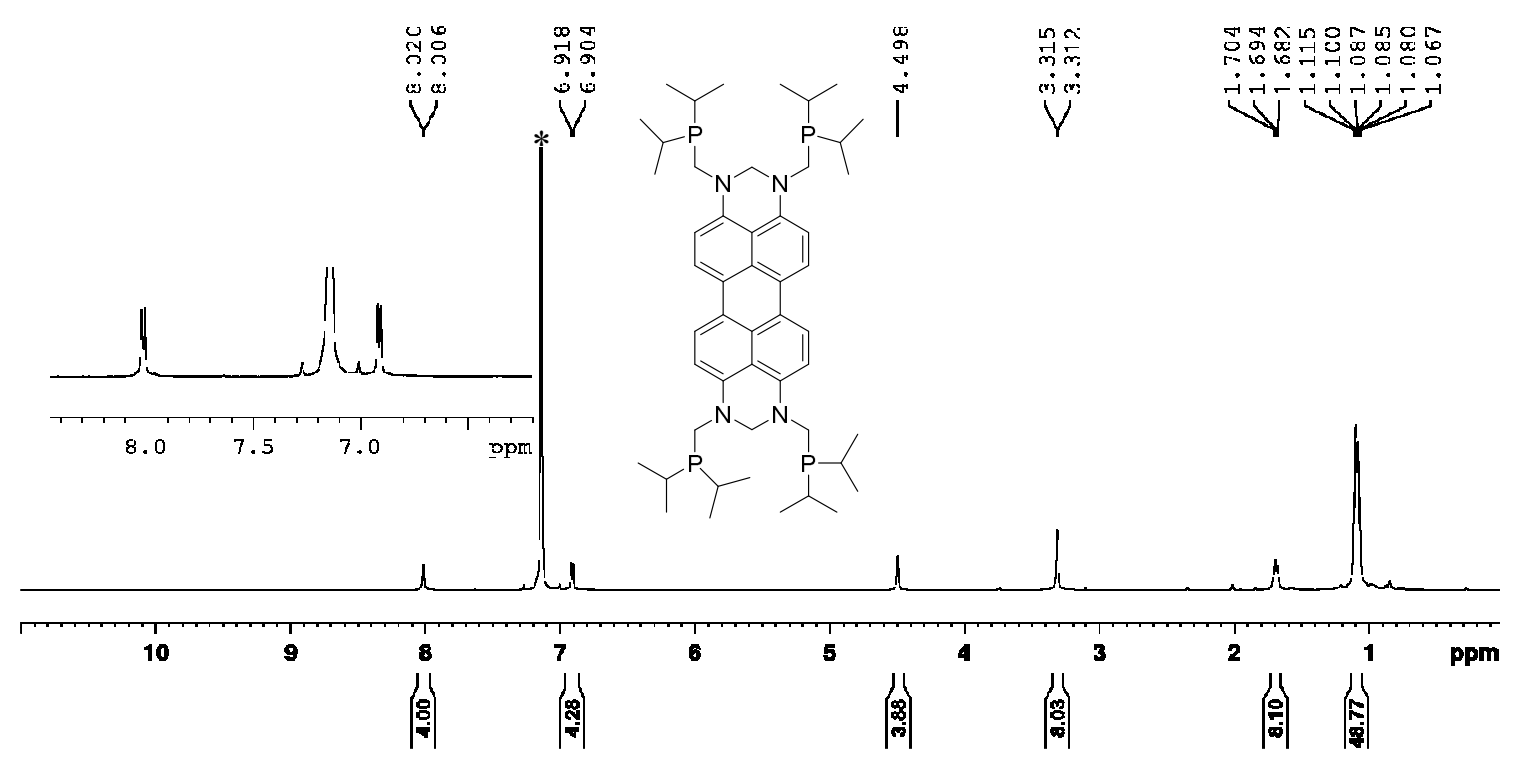

Figure S 10. ${ }^{1} \mathrm{H}$ NMR $\left(600.13 \mathrm{MHz}, \mathrm{C}_{6} \mathrm{D}_{6}\right)$ of 1c. Residual proton signal of $\mathrm{C}_{6} \mathrm{D}_{6}$ is labelled with *.

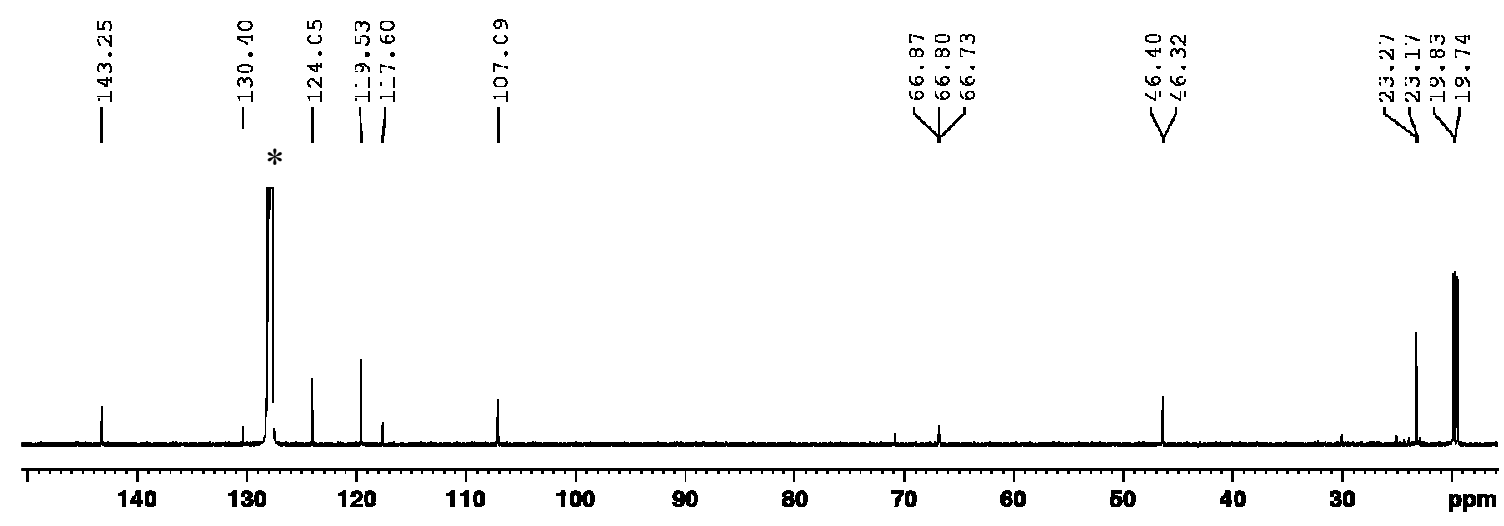

Figure S 11. ${ }^{13} \mathrm{C}$ NMR $\left(150.90 \mathrm{MHz}, \mathrm{C}_{6} \mathrm{D}_{6}\right)$ of 1c. Residual carbon signal of $\mathrm{C}_{6} \mathrm{D}_{6}$ is labelled with *.

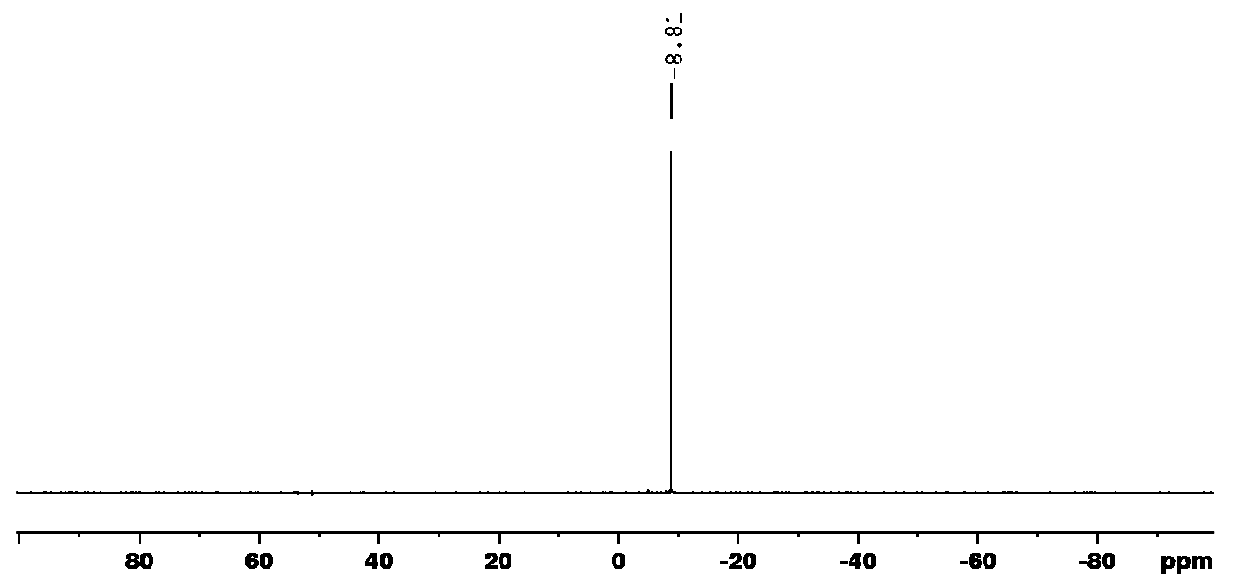

Figure S 12. ${ }^{31} \mathrm{P}$ NMR $\left(242.94 \mathrm{MHz}, \mathrm{C}_{6} \mathrm{D}_{6}\right)$ of $\mathbf{1 c}$. 


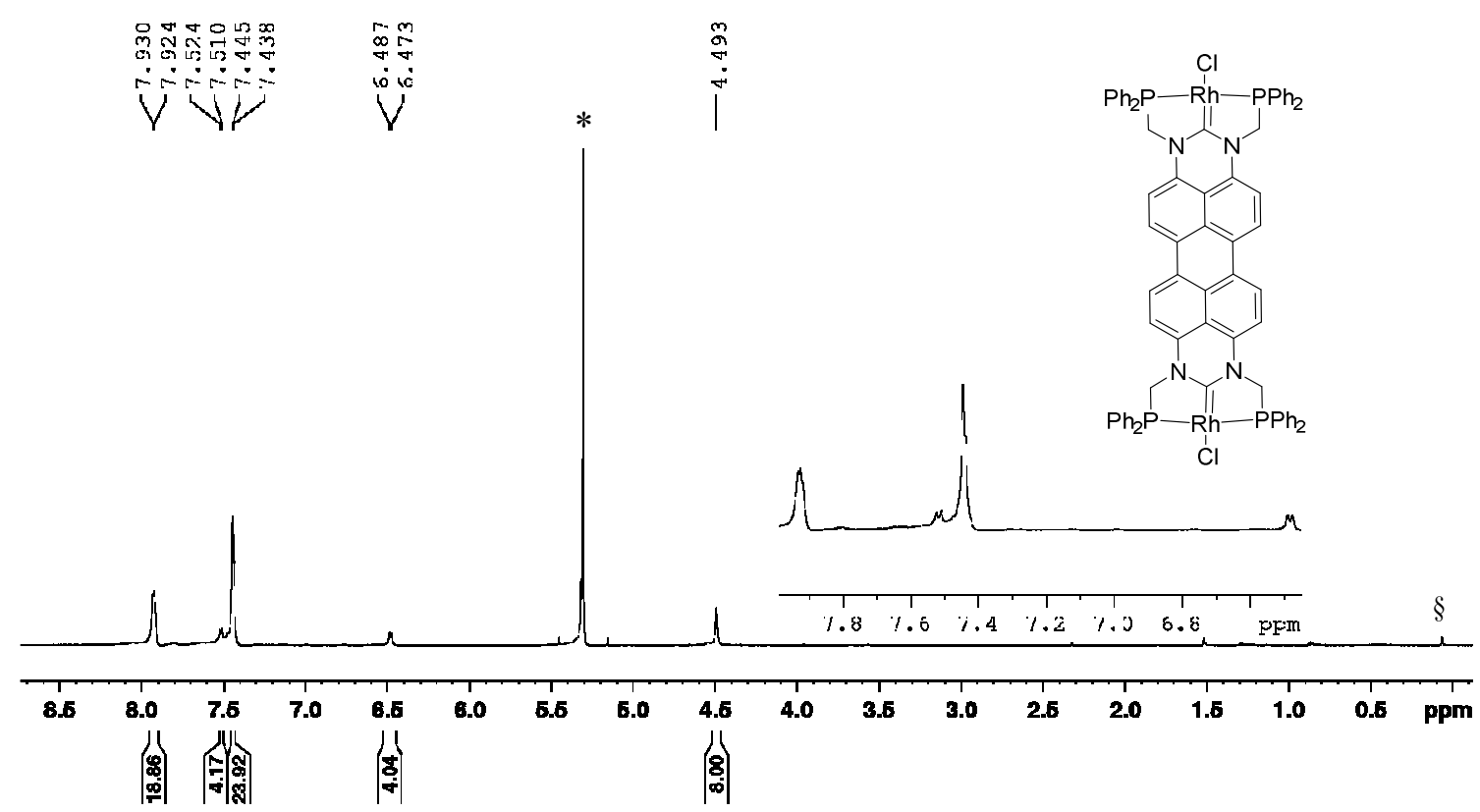

Figure $\mathbf{S}$ 13. ${ }^{1} \mathrm{H}$ NMR $\left(600.13 \mathrm{MHz}, \mathrm{CD}_{2} \mathrm{Cl}_{2}\right)$ of 2a. Silicon grease is labelled with $\S$ and residual proton signal of $\mathrm{C}_{2} \mathrm{Cl}_{2}$ with *.

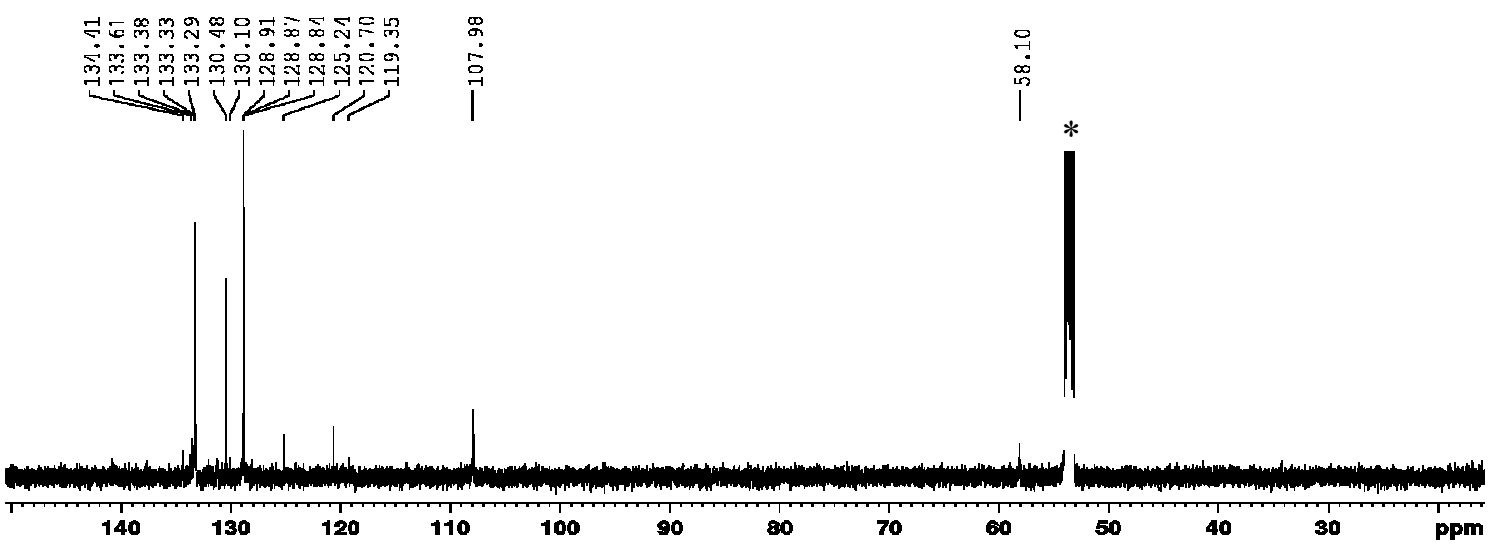

Figure $\mathrm{S}$ 14. ${ }^{13} \mathrm{C}$ NMR $\left(150.90 \mathrm{MHz}, \mathrm{CD}_{2} \mathrm{Cl}_{2}\right)$ of 2a. Residual carbon signal of $\mathrm{C}_{2} \mathrm{Cl}_{2}$ is labelled with *. 


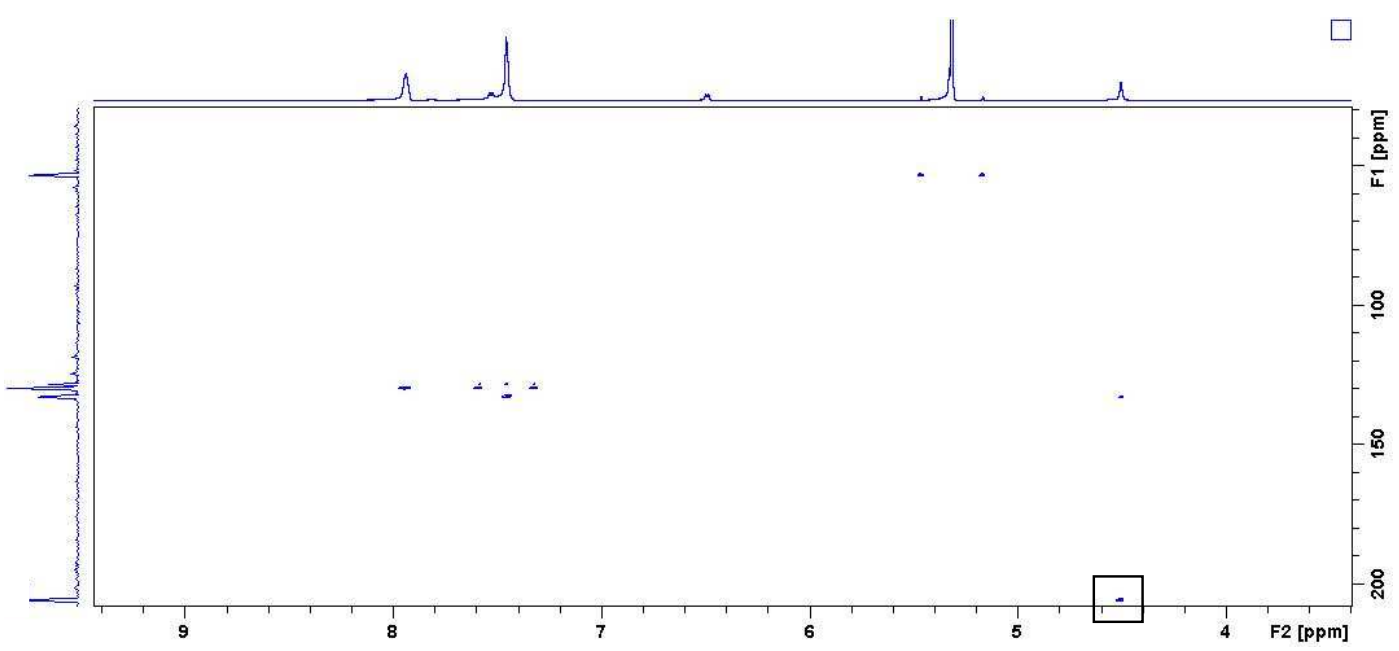

Figure S 15. 2D HMBC NMR (600.13 MHz/150.90 MHz, $\left.\mathrm{CD}_{2} \mathrm{Cl}_{2}\right)$ of $\mathbf{2 a}$.

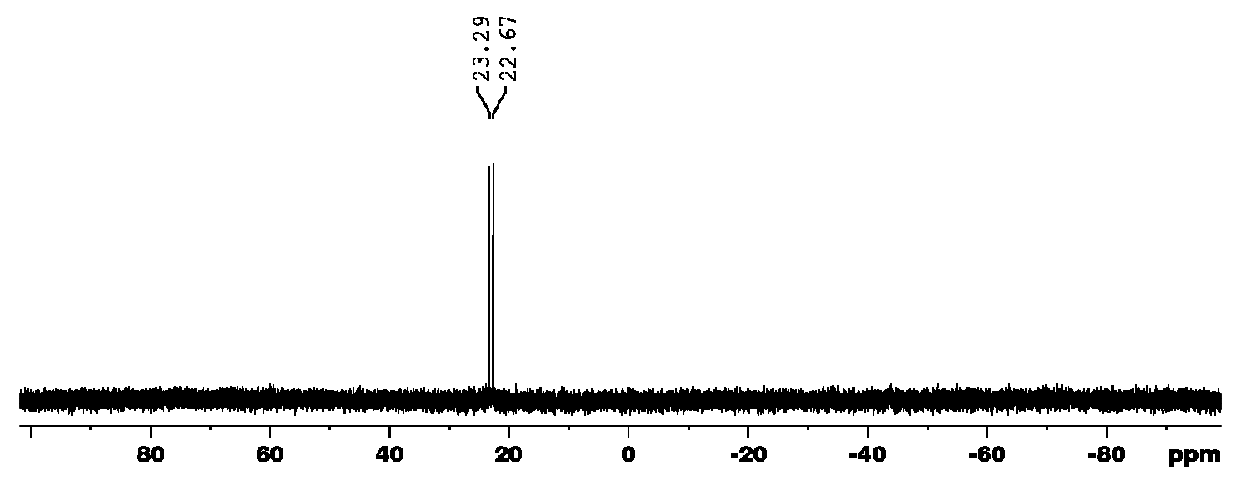

Figure $\mathbf{S}$ 16. ${ }^{31} \mathrm{P}$ NMR $\left(242.94 \mathrm{MHz}, \mathrm{CD}_{2} \mathrm{Cl}_{2}\right)$ of $\mathbf{2 a}$.

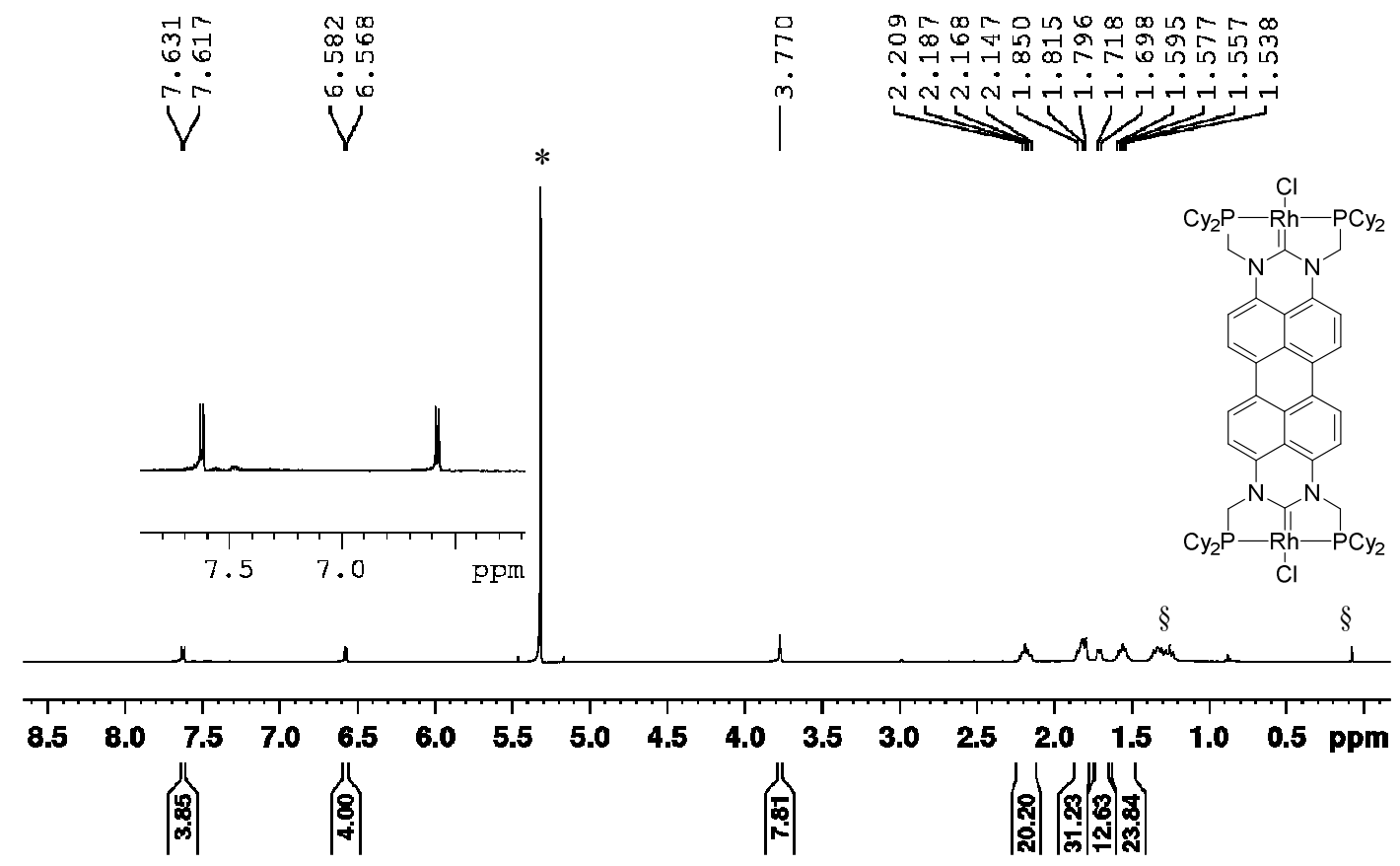

Figure S 17. ${ }^{1} \mathrm{H}$ NMR $\left(600.13 \mathrm{MHz}, \mathrm{CD}_{2} \mathrm{Cl}_{2}\right)$ of $\mathbf{2 b}$. Silicon grease and residual hexane are labelled with $\S$ and residual proton signal of $\mathrm{C}_{2} \mathrm{Cl}_{2}$ with *. 


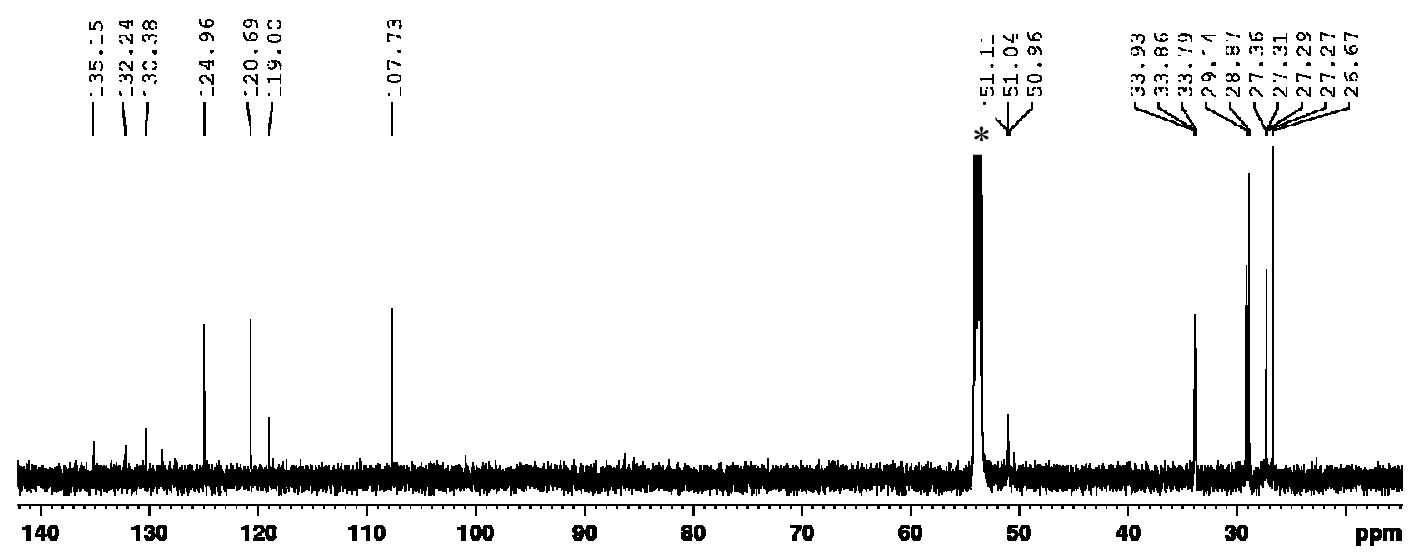

Figure S 18. ${ }^{13} \mathrm{C}$ NMR $\left(150.90 \mathrm{MHz}, \mathrm{CD}_{2} \mathrm{Cl}_{2}\right)$ of $\mathbf{2 b}$. Residual carbon signal of $\mathrm{C}_{2} \mathrm{Cl}_{2}$ is labelled with *.

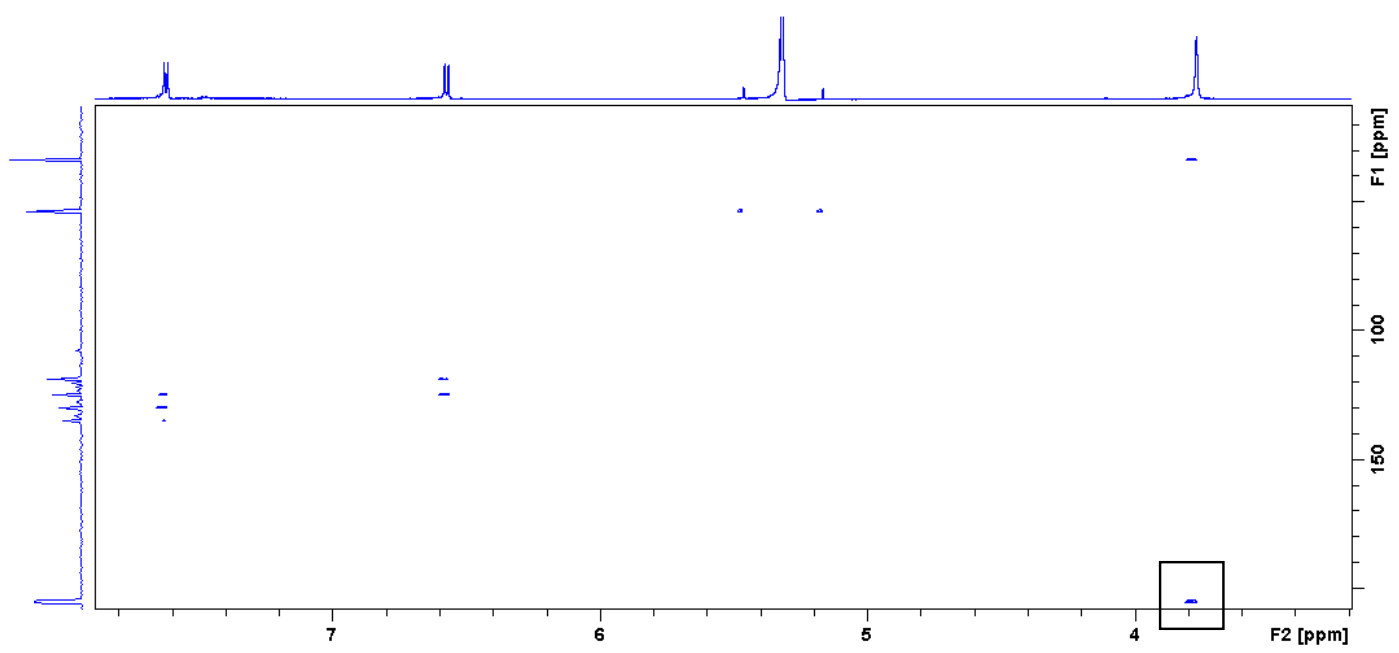

Figure S 19. Detail of 2D HMBC NMR (600.13 MHz/150.90 MHz, $\left.\mathrm{CD}_{2} \mathrm{Cl}_{2}\right)$ of $\mathbf{2 b}$.
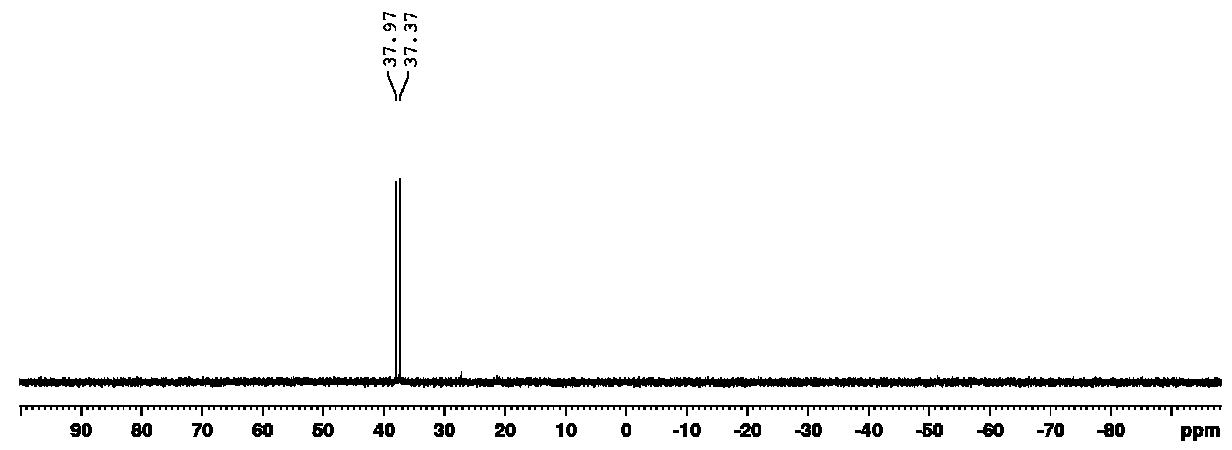

Figure S 20. ${ }^{31} \mathrm{P}$ NMR (242.94 MHz, $\left.\mathrm{CD}_{2} \mathrm{Cl}_{2}\right)$ of $\mathbf{2 b}$. 


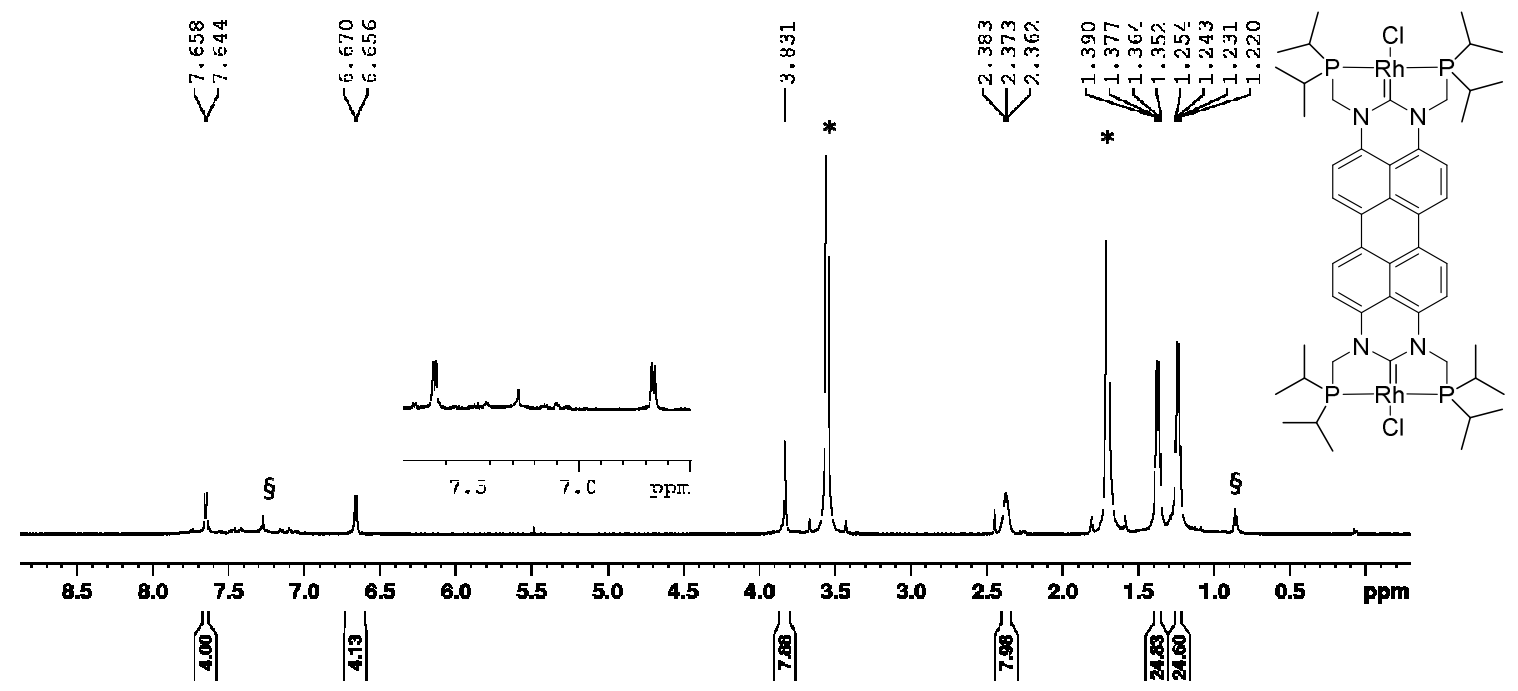

Figure S 21. ${ }^{1} \mathrm{H}$ NMR $\left(600.13 \mathrm{MHz}, \mathrm{THF}-\mathrm{d}_{8}\right)$ of 2 c. Silicon grease and unknowns impurities of the solvent are labelled with $\S$ and residual proton signal of THF- $\mathrm{d}_{8}$ with *.

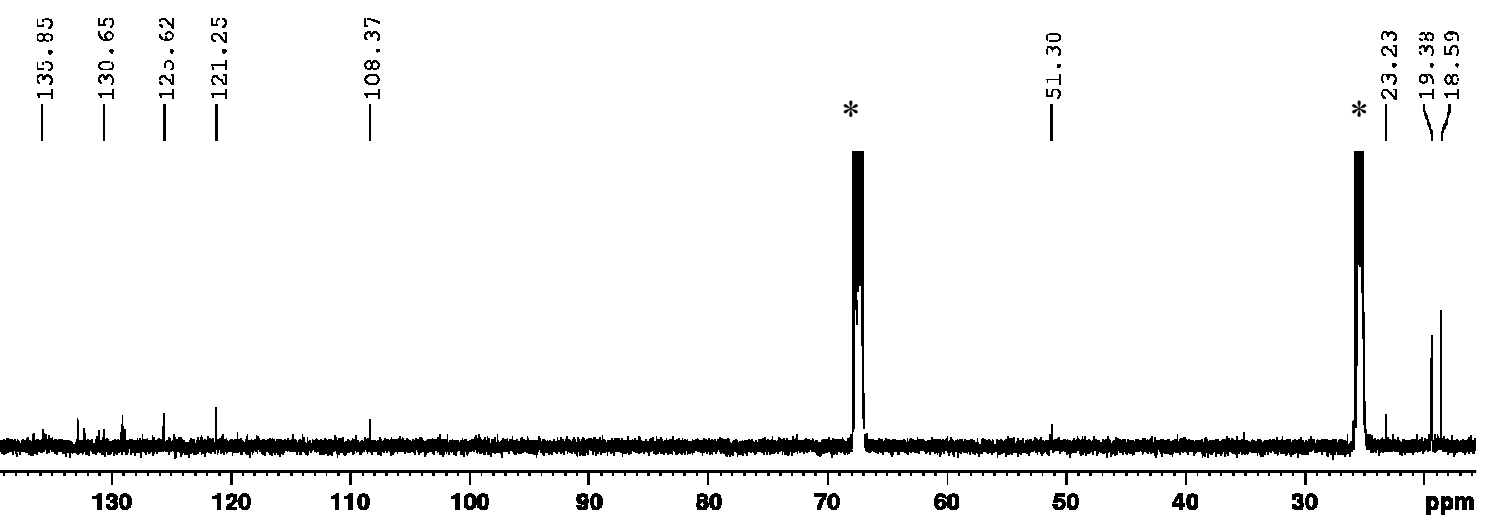

Figure S 22. ${ }^{13} \mathrm{C}$ NMR $\left(150.90 \mathrm{MHz}, \mathrm{THF}-\mathrm{d}_{8}\right)$ of 2c. Residual carbon signal of THF-d $\mathrm{d}_{8}$ is labelled with *.

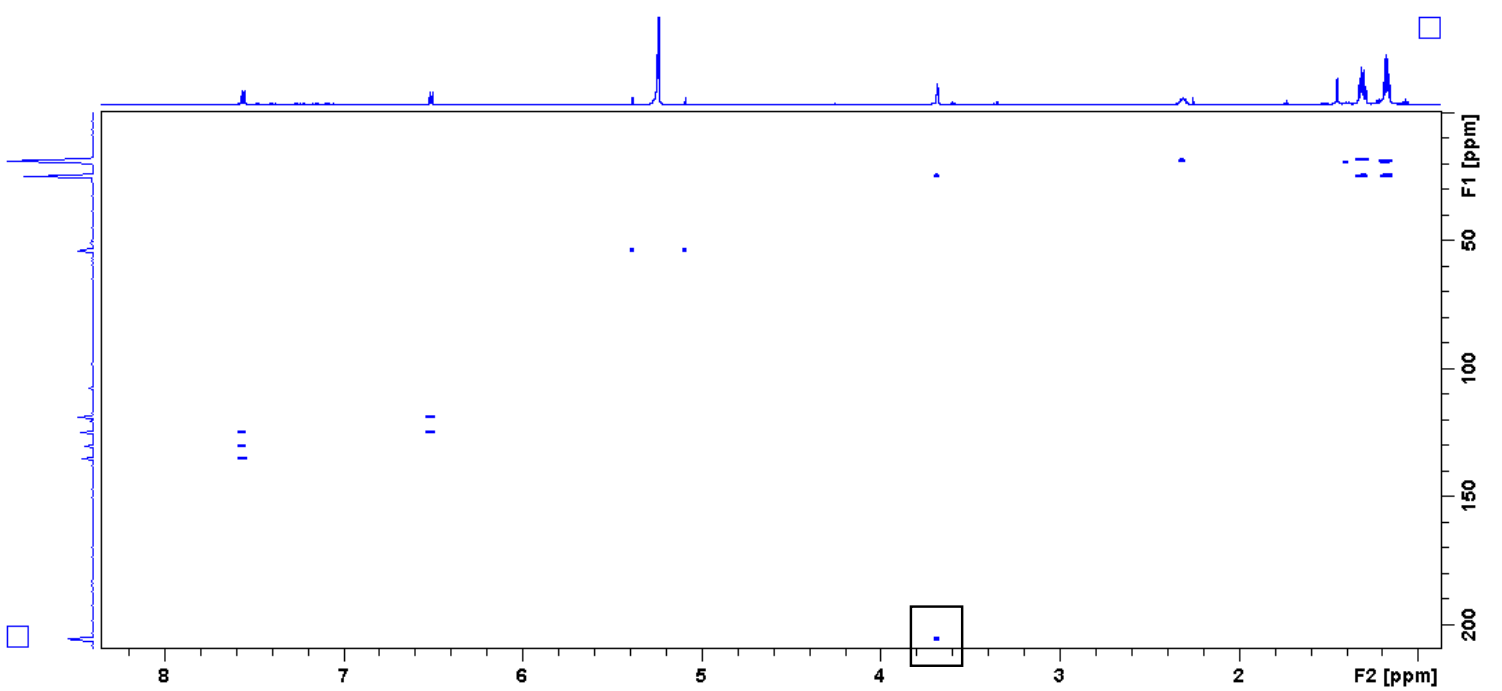

Figure S 23. Detail of 2D HMBC NMR (600.13 MHz/150.90 MHz, $\left.\mathrm{CD}_{2} \mathrm{Cl}_{2}\right)$ of $2 \mathbf{c}$. 


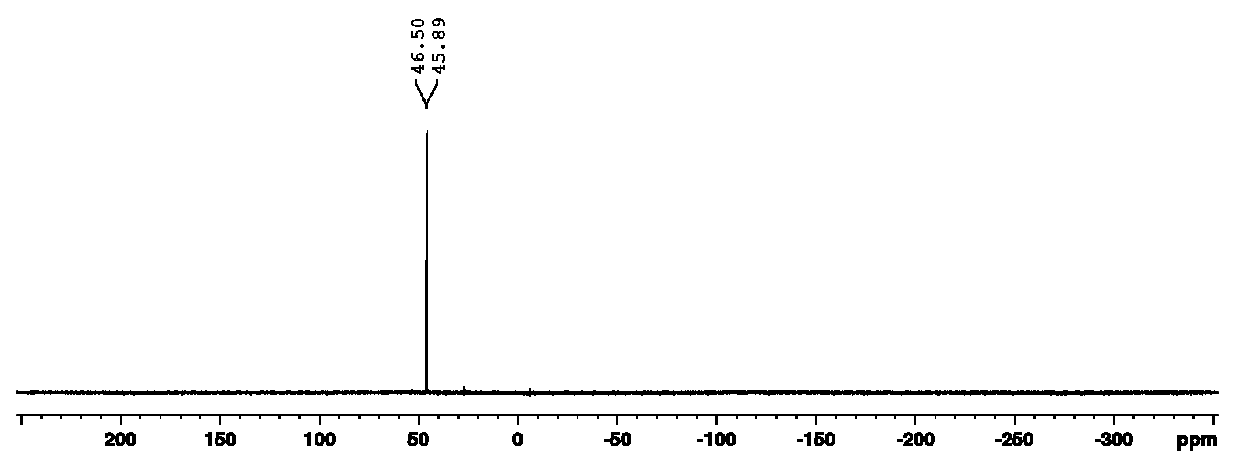

Figure S 24. ${ }^{31} \mathrm{P} \mathrm{NMR}\left(242.94 \mathrm{MHz}, \mathrm{CD}_{2} \mathrm{Cl}_{2}\right)$ of $\mathbf{2 c}$.

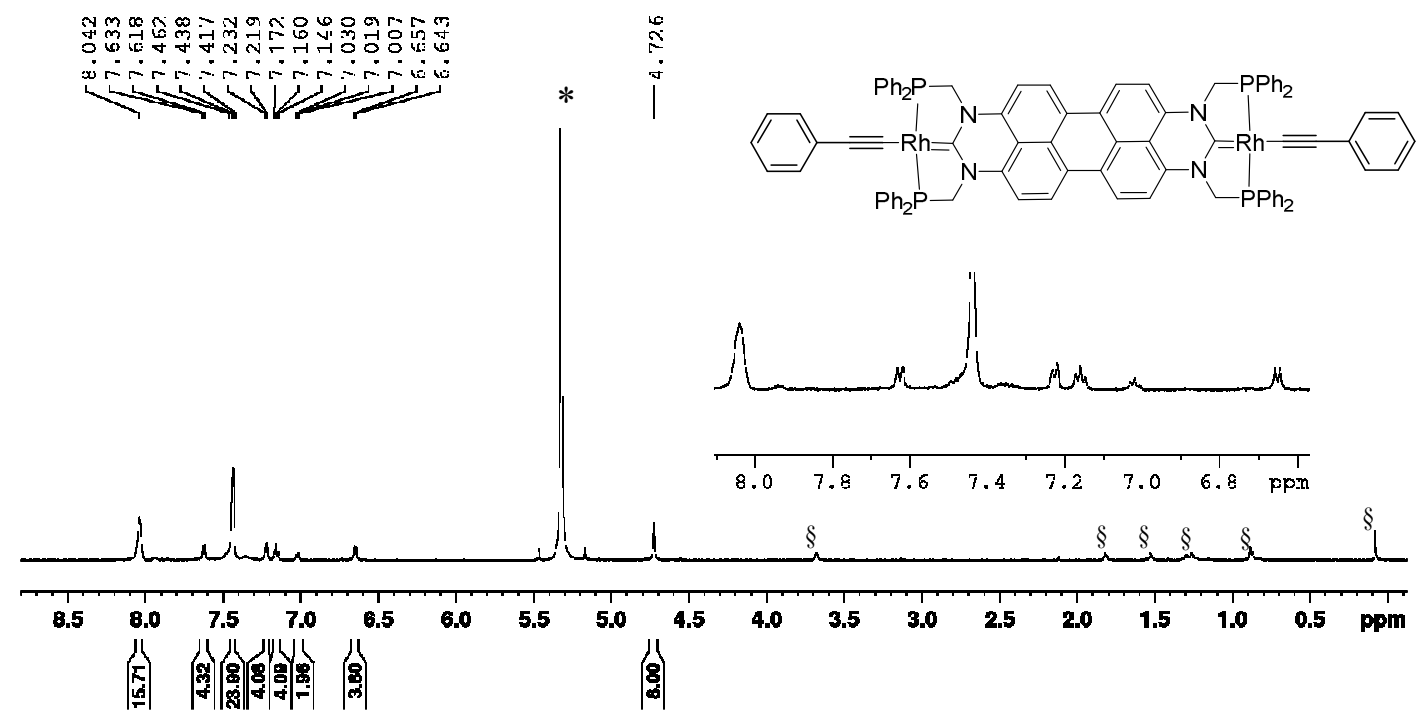

Figure S 25. ${ }^{1} \mathrm{H}$ NMR $\left(600.13 \mathrm{MHz}, \mathrm{CD}_{2} \mathrm{Cl}_{2}\right)$ of 3a. Silicon grease and unknowns impurities are labelled with $\S$ and residual proton signal of $\mathrm{CD}_{2} \mathrm{Cl}_{2}$ with *.

$$
\text { ஸั่ }
$$

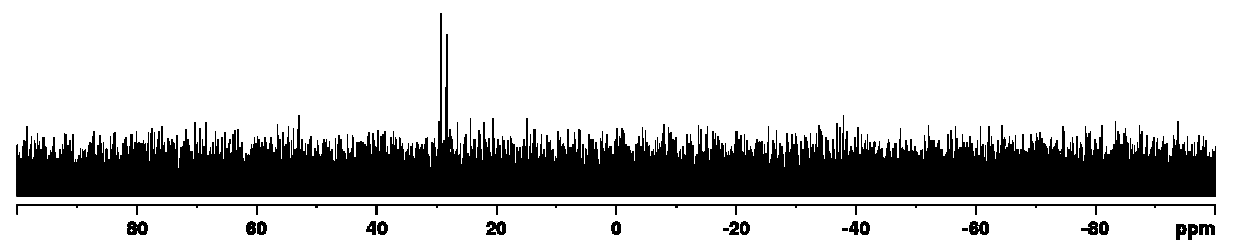

Figure S 26. ${ }^{31} \mathrm{P}$ NMR $\left(242.94 \mathrm{MHz}, \mathrm{CD}_{2} \mathrm{Cl}_{2}\right)$ of $\mathbf{3 a}$. 


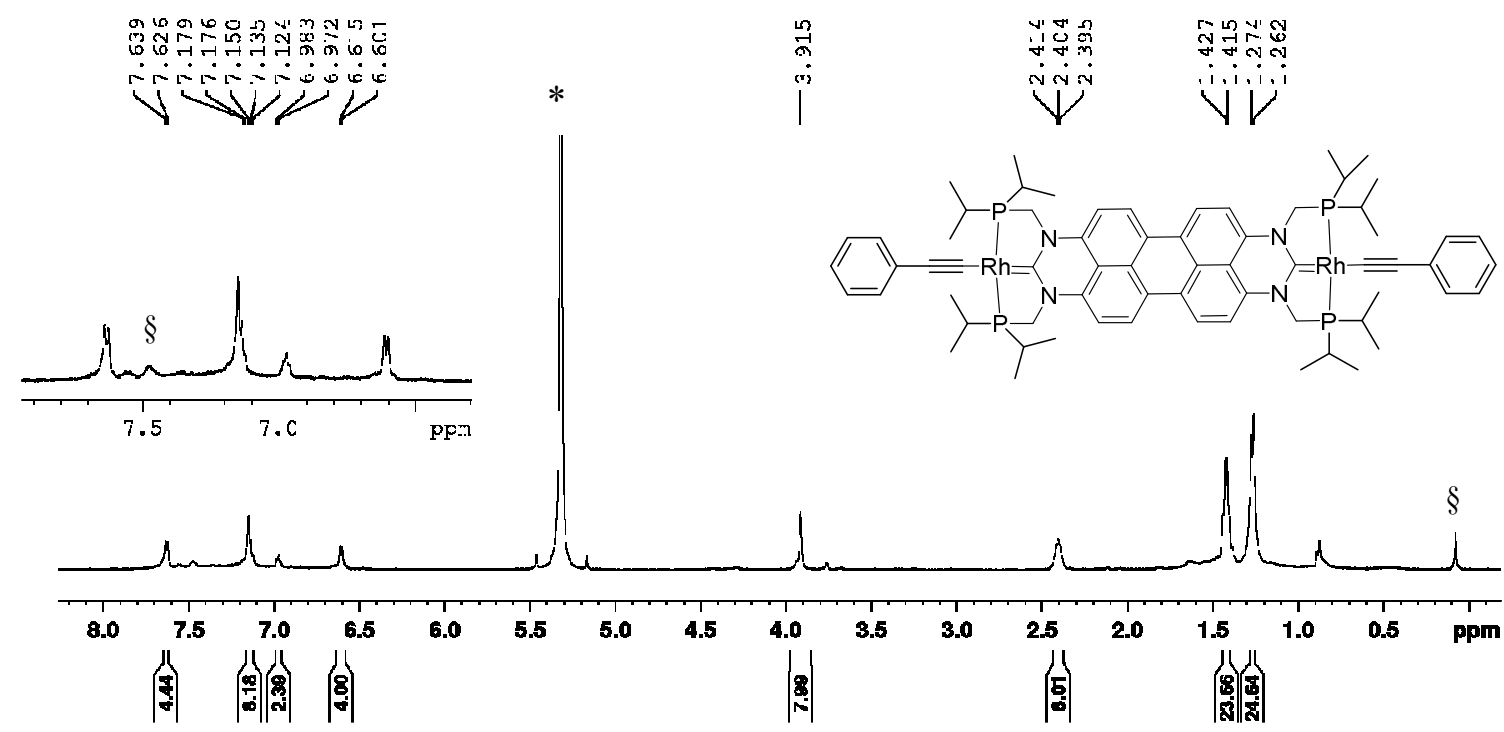

Figure $\mathbf{S} 27 .{ }^{1} \mathrm{H}$ NMR $\left(600.13 \mathrm{MHz}, \mathrm{CD}_{2} \mathrm{Cl}_{2}\right)$ of $\mathbf{3 b}$. Silicon grease and unknown impurities are labelled with $\S$ and residual proton signal of $\mathrm{CD}_{2} \mathrm{Cl}_{2}$ with *.

$$
\text { ทั่ }
$$

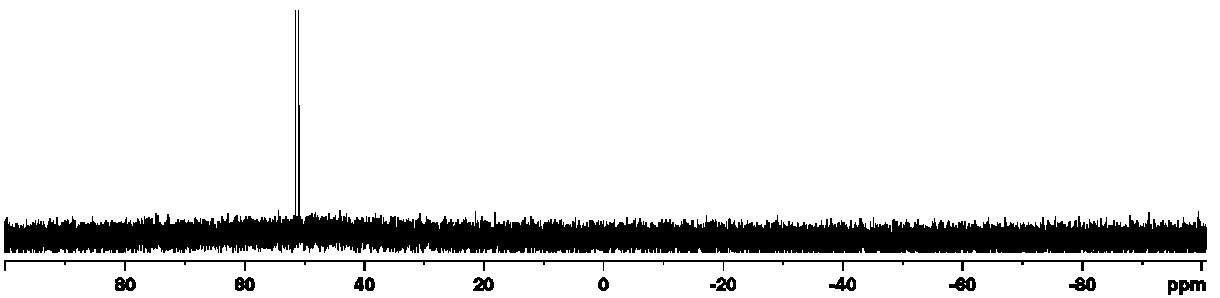

Figure S 28. ${ }^{31} \mathrm{P}$ NMR $\left(242.94 \mathrm{MHz}, \mathrm{CD}_{2} \mathrm{Cl}_{2}\right)$ of $\mathbf{3 b}$.

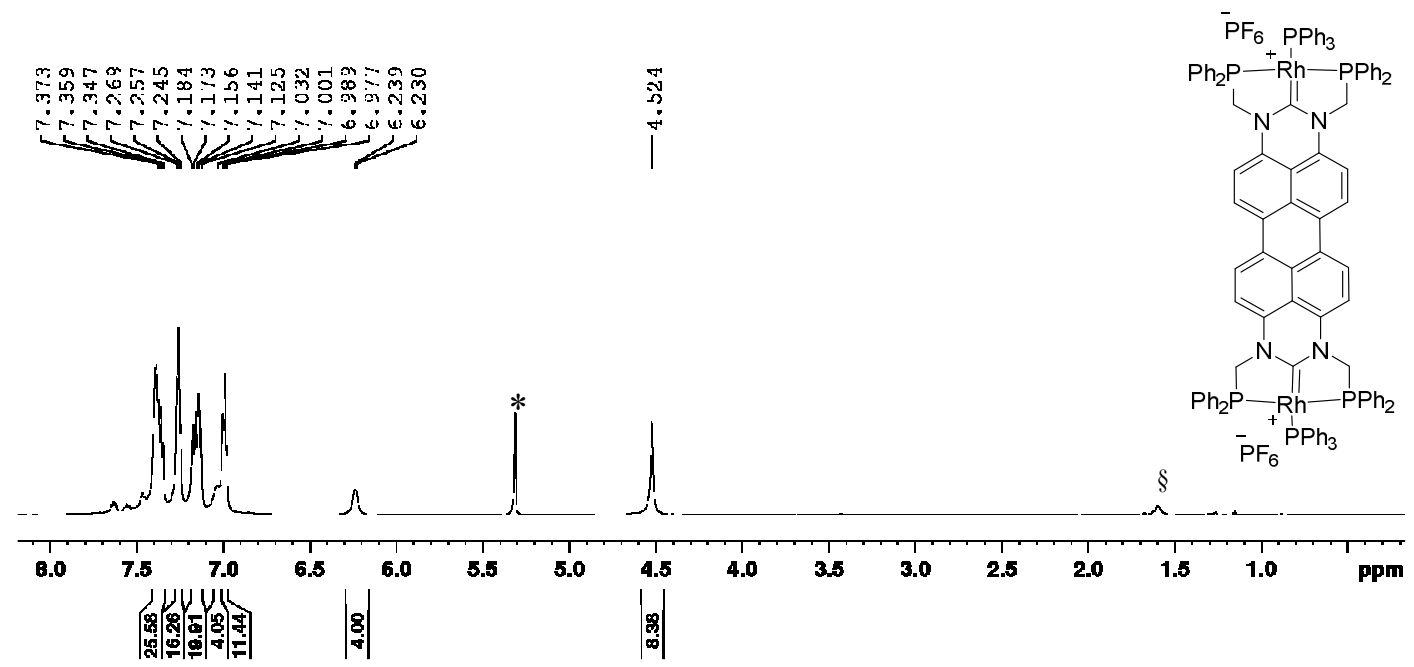

Figure $\mathbf{S}$ 29. ${ }^{1} \mathrm{H}$ NMR $\left(600.13 \mathrm{MHz}, \mathrm{CD}_{2} \mathrm{Cl}_{2}\right)$ of 4a. Unknown impurities are labelled with $\S$ and residual proton signal of $\mathrm{CD}_{2} \mathrm{Cl}_{2}$ with *. 


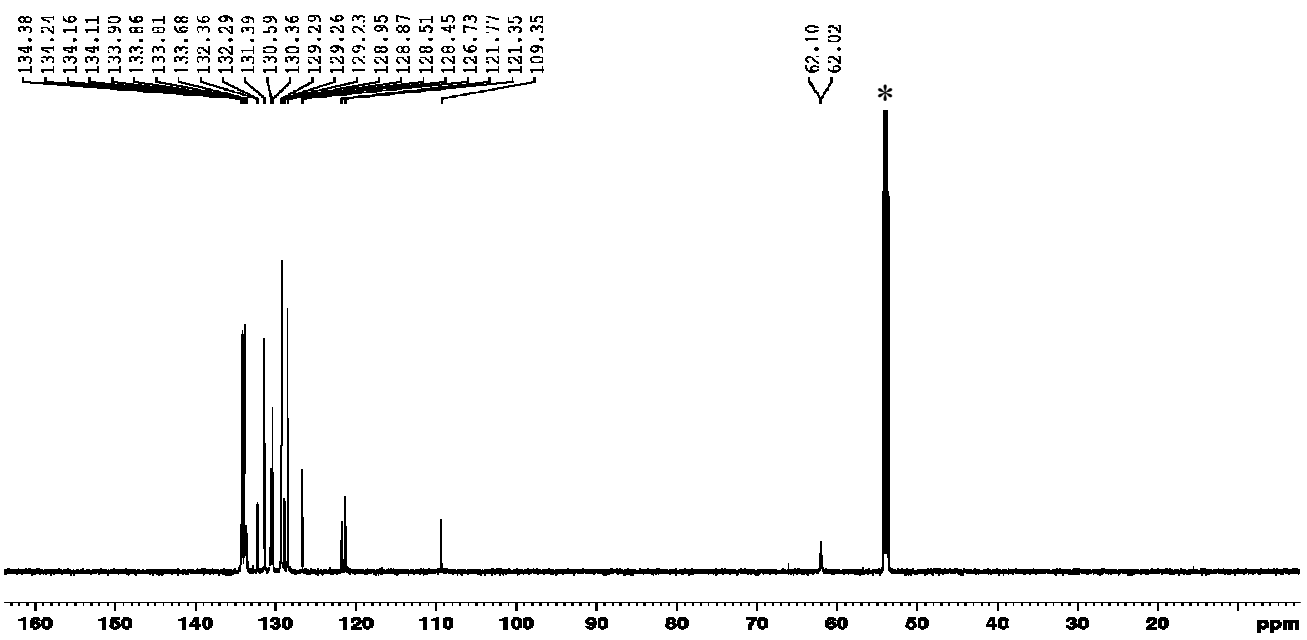

Figure S 30. ${ }^{13} \mathrm{C}$ NMR $\left(150.90 \mathrm{MHz}, \mathrm{CD}_{2} \mathrm{Cl}_{2}\right)$ of 4a. Residual proton signal of THF- $\mathrm{d}_{8}$ with *.

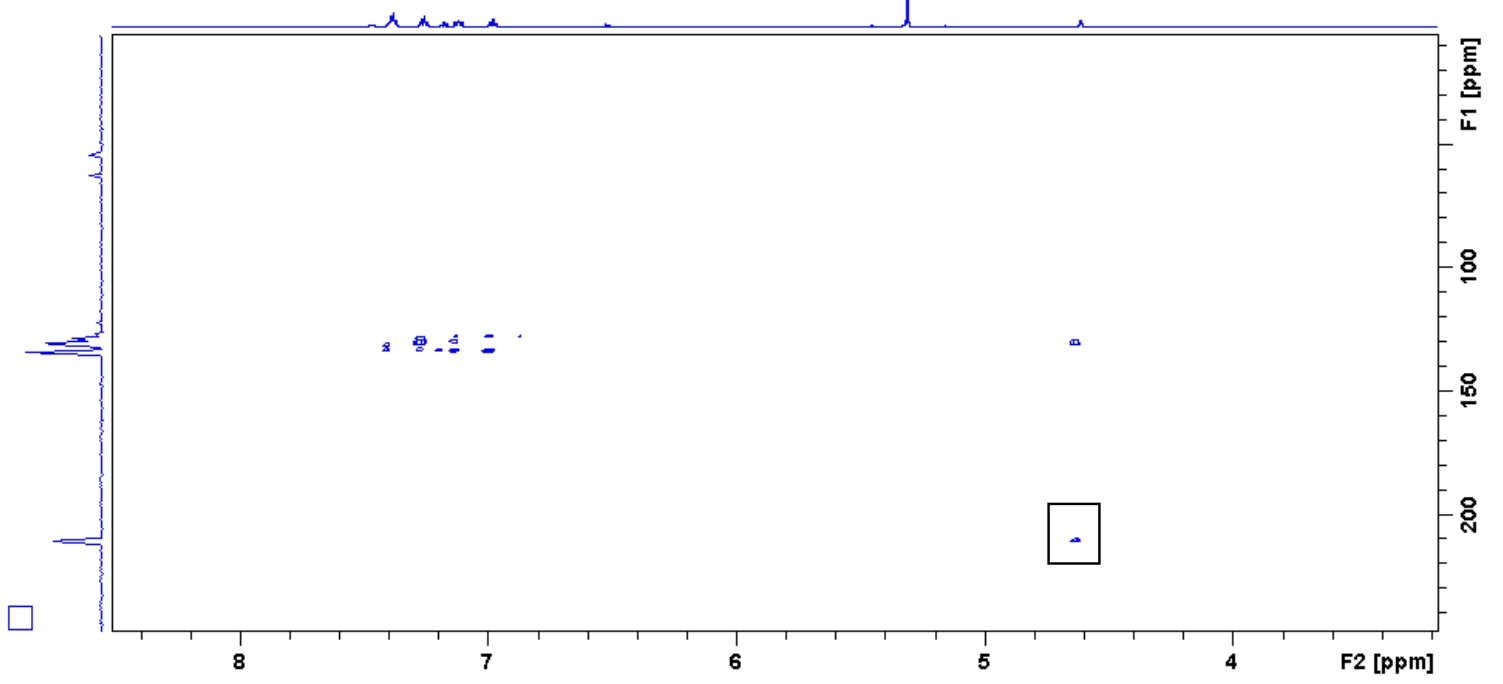

Figure S 31. Detail of 2D HMBC NMR (600.13 MHz/150.90 MHz, $\left.\mathrm{CD}_{2} \mathrm{Cl}_{2}\right)$ of $\mathbf{4 a}$.
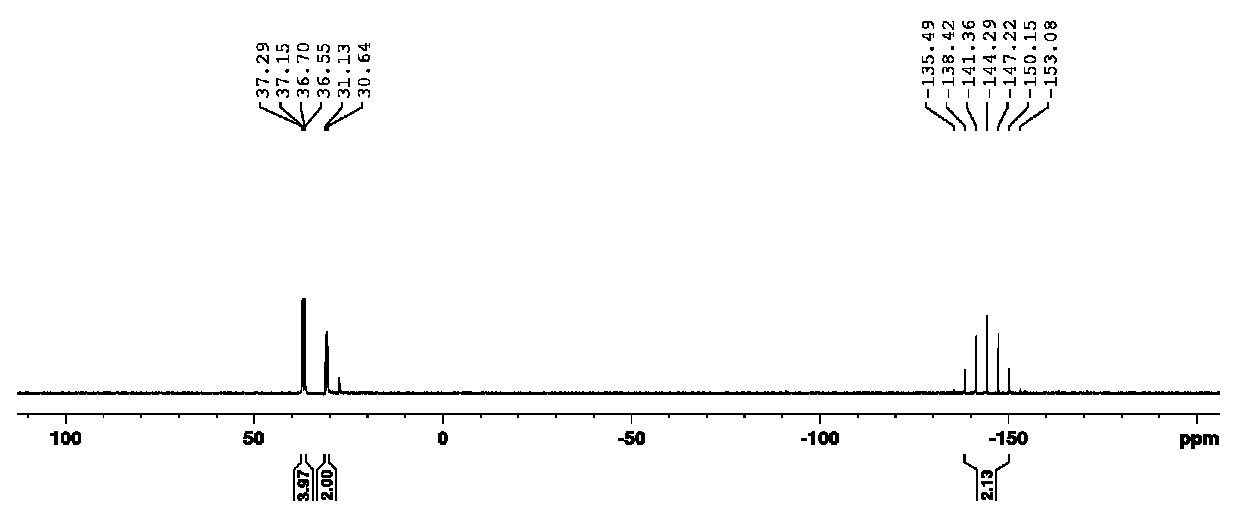

Figure S 32. ${ }^{31} \mathrm{P}$ NMR $\left(242.94 \mathrm{MHz}, \mathrm{CD}_{2} \mathrm{Cl}_{2}\right)$ of $\mathbf{4 a}$. 


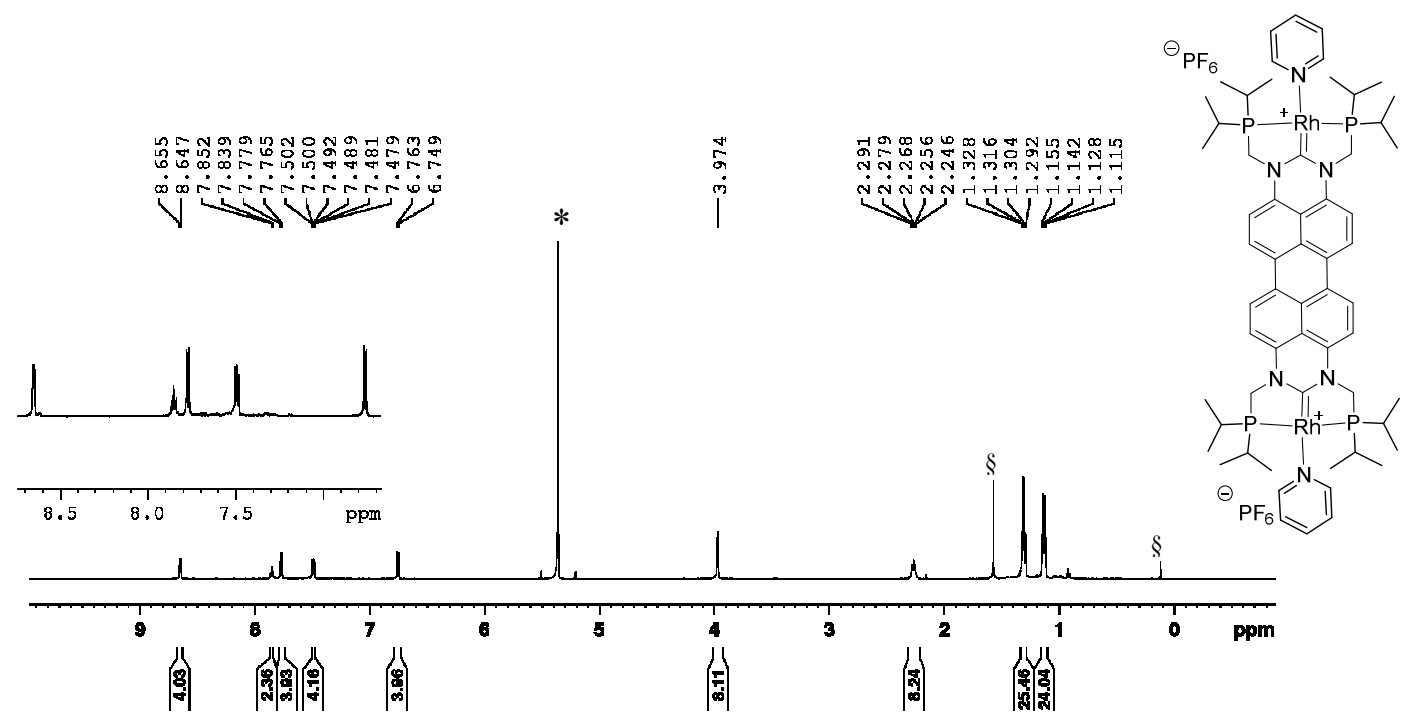

Figure S 33. ${ }^{1} \mathrm{H}$ NMR $\left(600.13 \mathrm{MHz}, \mathrm{CD}_{2} \mathrm{Cl}_{2}\right)$ of $\mathbf{4 b}$. Water and silicon grease are labelled with $\S$ and residual proton signal of $\mathrm{CD}_{2} \mathrm{Cl}_{2}$ with *.

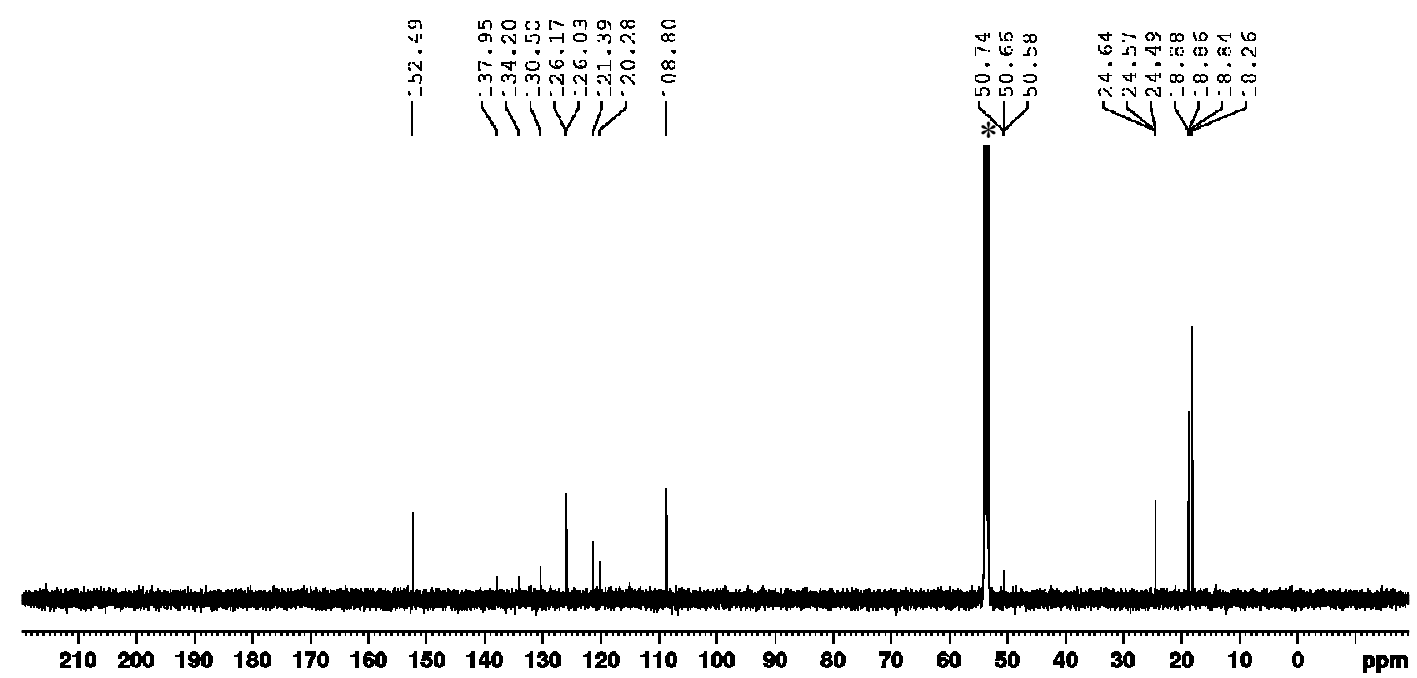

Figure S 34. ${ }^{13} \mathrm{C}$ NMR $\left(150.90 \mathrm{MHz}, \mathrm{CD}_{2} \mathrm{Cl}_{2}\right)$ of $\mathbf{4 b}$. Residual proton signal of THF- $\mathrm{d}_{8}$ with *. 


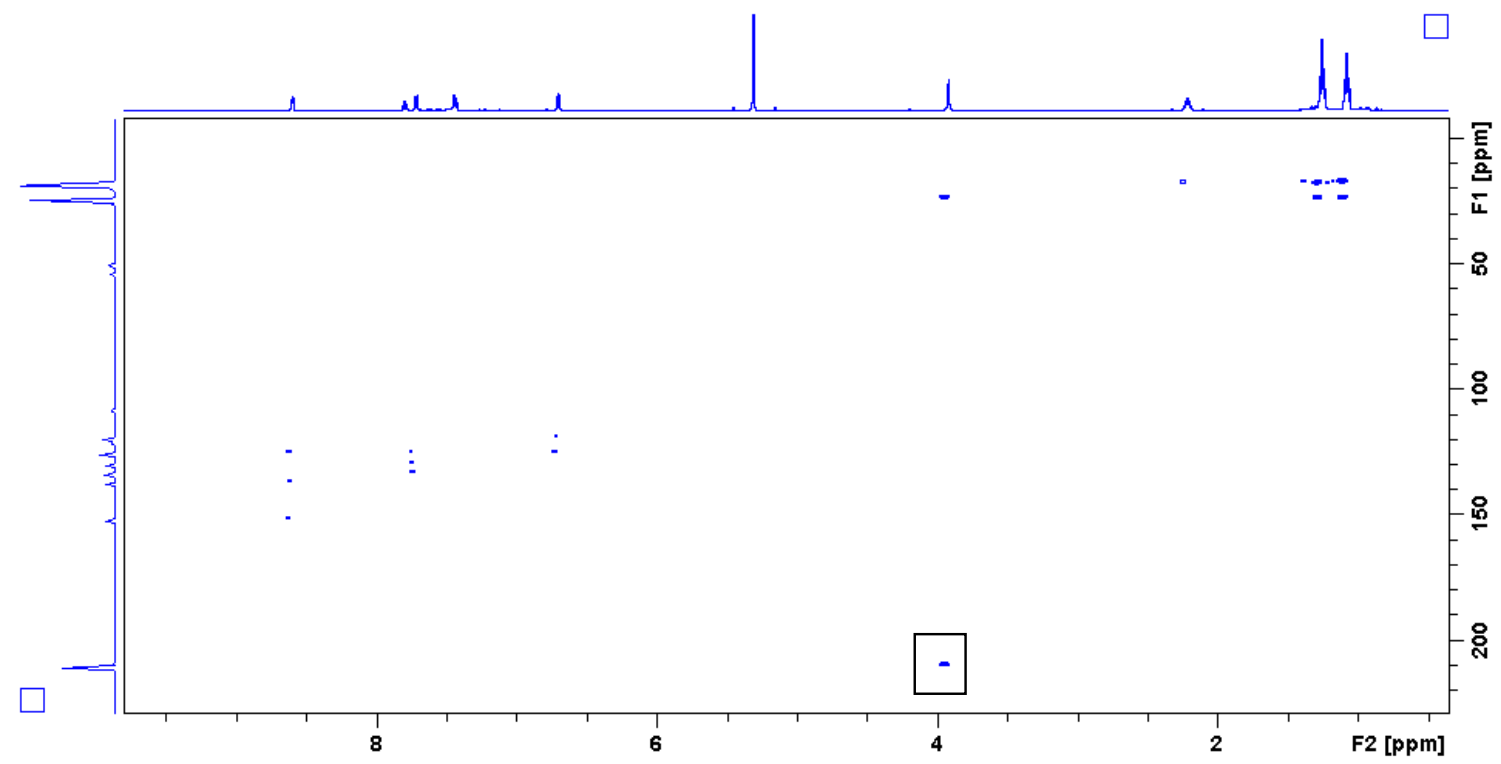

Figure $\mathbf{S} 35$. Detail of 2D HMBC NMR (600.13 MHz/150.90 MHz, $\left.\mathrm{CD}_{2} \mathrm{Cl}_{2}\right)$ of $\mathbf{4 b}$.

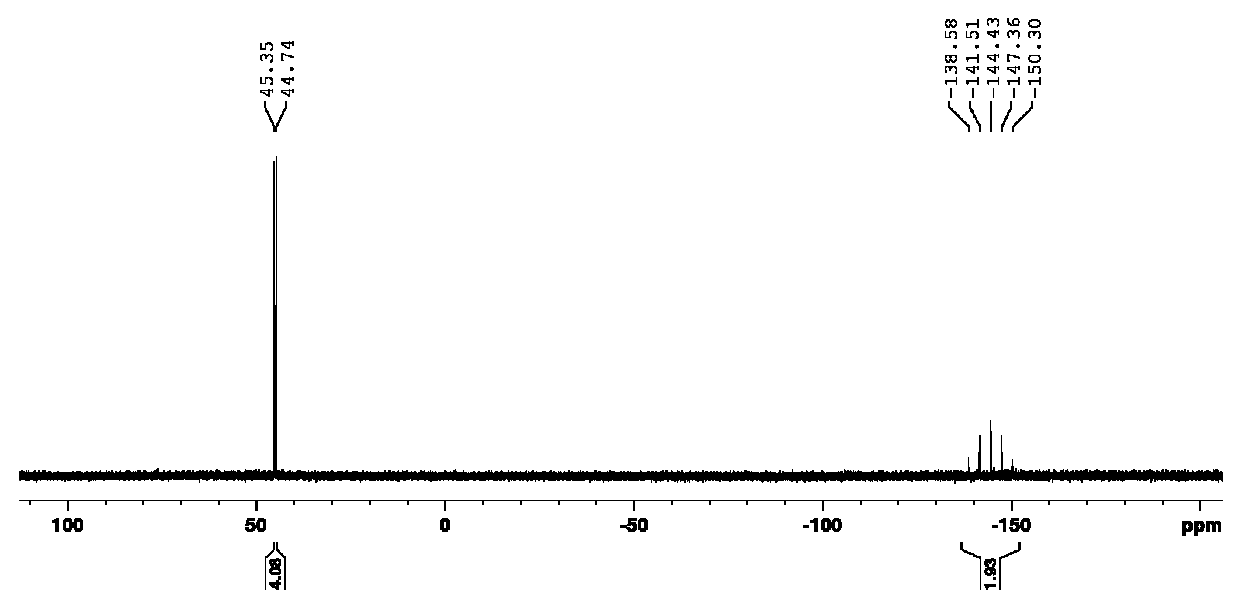

Figure S 36. ${ }^{31} \mathrm{P}$ NMR $\left(242.94 \mathrm{MHz}, \mathrm{CD}_{2} \mathrm{Cl}_{2}\right)$ of $\mathbf{4 b}$.
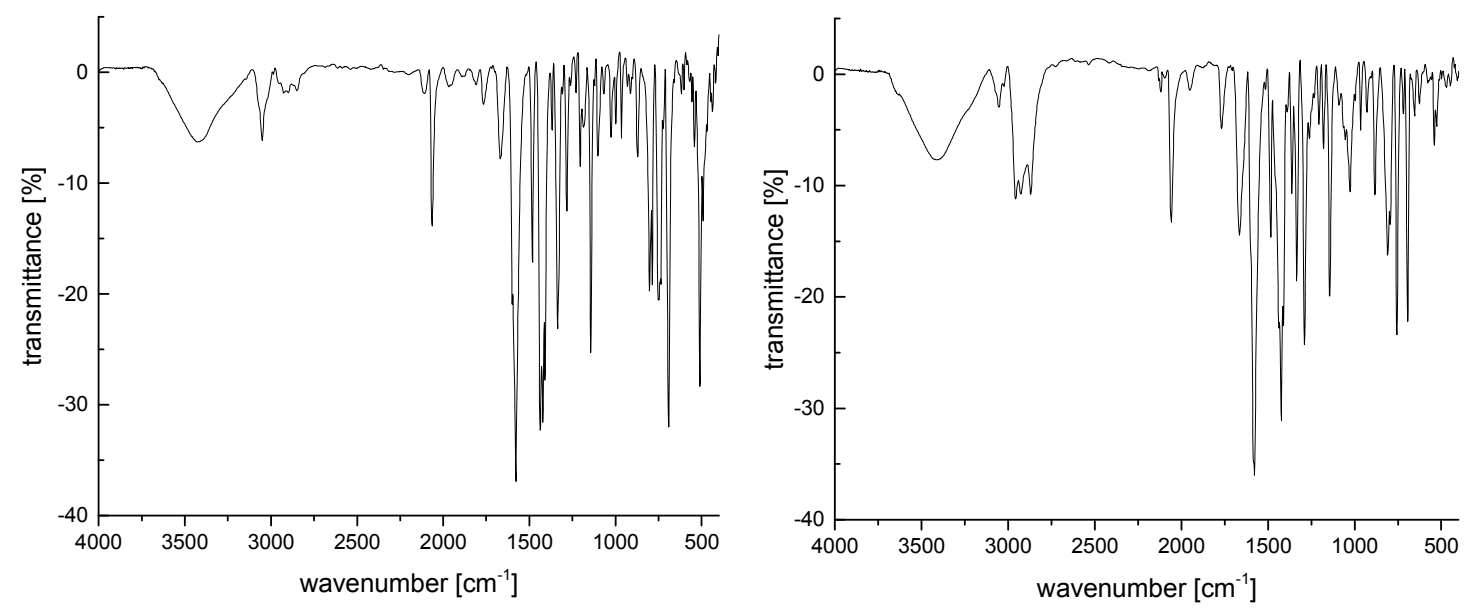

Figure S 37. IR spectra of 3a (left) and $\mathbf{3 b}$ (right) using $\mathrm{KBr}$ pellets. 

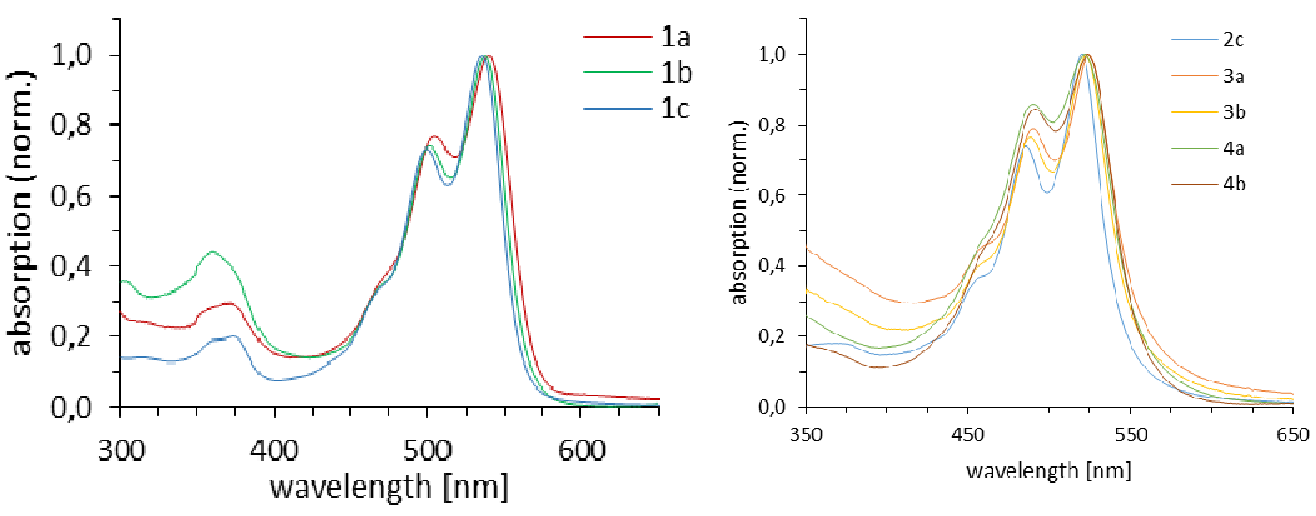

Figure S 38. Normalized absorption spectra of 1a-1b (left) and the complexes $\mathbf{2 c}, \mathbf{3 a - 3 b}, \mathbf{4 a - 4 b}$ (right).
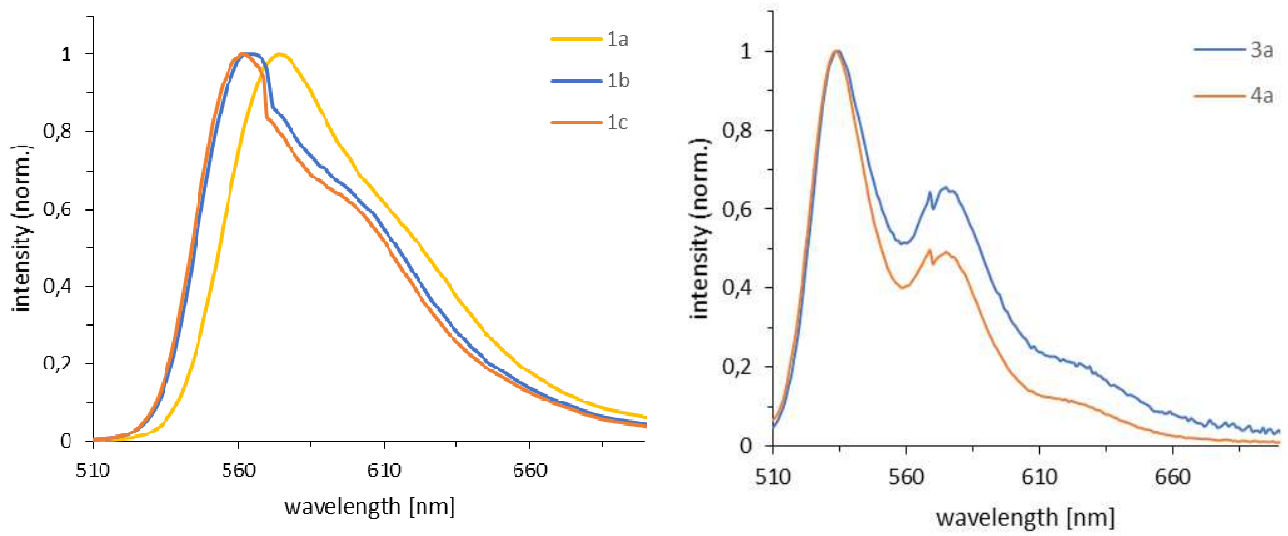

Figure S 39. Normalized emission spectra of 1a-1b (left) and complexes 3a and 4a (right).
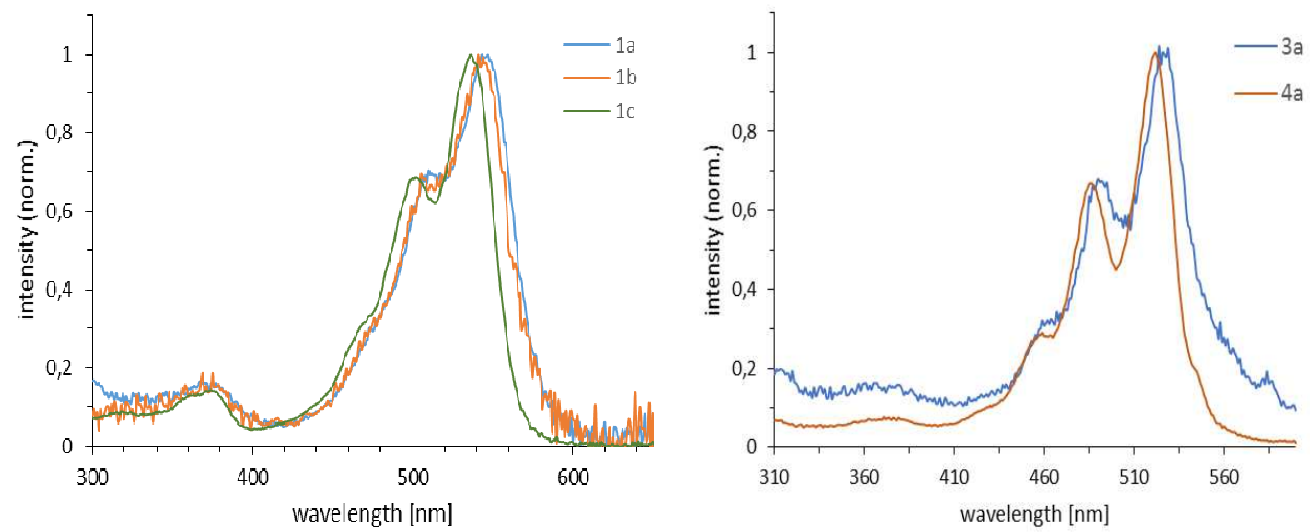

Figure S 40. Normalized excitation fluorescence spectra of 1a-1c (left) and complexes 3a and 4a (right). 